\title{
Investor Protection and Dividend Policy: The Case of Islamic and Conventional Banks
}

\author{
Seyed Alireza Athari
}

\author{
Submitted to the \\ Institute of Graduate Studies and Research \\ in partial fulfillment of the requirements for the degree of
}

Doctor of Philosophy

in

Finance

Eastern Mediterranean University

August 2016

Gazimağusa, North Cyprus 
Approval of the Institute of Graduate Studies and Research

Prof. Dr. Mustafa Tümer Acting Director

I certify that this thesis satisfies the requirements as a thesis for the degree of Doctor of Philosophy in Finance.

Assoc. Prof. Dr. Nesrin Özataç

Chair, Department of Banking and Finance

We certify that we have read this thesis and that in our opinion it is fully adequate in scope and quality as a thesis for the degree of Doctor of Philosophy in Finance.

Prof. Dr. Eralp Bektaş
Co-Supervisor

\begin{tabular}{c}
\hline Prof. Dr. Cahit Adaoğlu \\
Supervisor
\end{tabular}

Examining Committee

1. Prof. Dr. Cahit Adaoğlu

2. Prof. Dr. Eralp Bektaş

3. Prof. Dr. Hatice Doğukanlı

4. Prof. Dr. Halil Seyidoğlu

5. Assoc. Prof. Dr. Nesrin Özataç 


\begin{abstract}
This study examines the dividend policy behavior of Islamic and conventional banks operating in Arab markets. I examine countries included in Gulf Cooperation Council and Middle East and North Africa. These banks operate in an environment characterized by Sharia law and low levels of investor protection. I expect that in Arab countries, financial institutions have more potential to exploit the minority shareholders by using the dividend policy. I also expect that within the framework of agency theory, both types of banks set their dividend policies differently.
\end{abstract}

By using the dynamic partial adjustment dividend model for the period 2003-2012, I find that both types of banks follow stable dividend policies having the similar speed of adjustment coefficients. However, conventional banks have relatively more stable and less responsive dividend policies to the changes of earnings. Contrary to the agency theory predictions of higher actual and target dividend payout ratios for Islamic banks, both ratios are substantially lower. Islamic banks in these markets have relatively more willing to payout less dividends and use free cash flow for their personal benefits. In contrast, conventional banks experience relatively less significant agency problems and have more willing to payout higher dividends.

The empirical results also show that in an environment characterized by Sharia law and low levels of investor protection, Islamic and conventional banks set their dividend policies in line with substitute and outcome agency model of dividends, respectively. Islamic banks payout lower dividends and use the dividend policy as a substitute mechanism for alleviating relatively more significant agency problems. Sub- 
classification index results show that Islamic banks increase dividends in response to weak minority investor protection, specifically the inability of shareholders to get corporate documents during litigation against firms. In these markets, conventional banks payout higher dividends as an outcome of strong protection for shareholder rights. Sub-classification index results show that conventional banks increase dividends in response to stronger minority investor protection, specifically for the director liability and the amount of disclosure of related party transactions.

Keywords: dividend policy; stability; agency theory; outcome; substitute; Islamic banks; conventional banks 


\section{ÖZ}

$\mathrm{Bu}$ çalışma Arap piyasasında faaliyet gösteren geleneksel ve İslam bankalarının temettü politika davranışlarını incelemektedir. Körfez Arap Ülkeleri İşbirliği Konseyi üyesi, Ortadoğu ve Kuzey Afrika bölge ülkeleri inceleme kapsamındadır. Bu bankalar, şeriat kuralları tarafından uygulandığı ve düşük yatırımcı koruması olan bir ortamda işletilmektedirler. Beklentimiz, Arap ülkelerindeki finansal kurumların temettü politikası aracılığı ile azınlık hissedarlarını istismar edecek olmasıdır. Ayrıca, vekâlet teorisi kapsamında, her iki banka türünde farklı temettü politikaları izlemesini beklemektedir.

2003-2012 yılları arasında dinamik kısmi uyarlama modeli uygulayarak, her iki banka türünün benzer uyarlama hızı katsayıları ile istikrarlı bir temettü politikası izlediği tespit edilmiştir. Bununla beraber, geleneksel bankalar kazanç değişimleri karşısında daha istikrarlı ve daha yavaş uyarlama hızı gösteren temettü politikası izlemektedirler. Vekâlet teorisi çerçevesinde gerçek ve hedef temettü oranlarının daha yüksek olması beklentisinin aksine, İslam bankalarında bu oranlar daha düşüktür. Bu piyasalarda, İslam bankaları daha az temettü ödemesi yapıp, serbest nakit akışlarını kişisel faydalar için kullanmaktadırlar. Bunun aksine, geleneksel bankalar daha az vekâlet maliyet olmasına rağmen daha fazla temettü ödemesi yaptıkları gözlemlenmiştir.

Ampirik sonuçlar göstermiştir ki, şeriat kuralları ve düşük yatırımcı koruması olan bir ortamda, İslam bankaları temettü politikalarını yerine vekâlet modeli çerçevesinde uygularken, geleneksel bankalar sonuç vekâlet modelini 
benimsemektedirler. Alt-sınıflandırma endeks sonuçları göstermiştir ki İslam bankaları temettü ödemelerini zayıf azınlık korumasına tepki olarak ve özellikle firmalara karşı açılan dava süresince hissedarların kurumsal belgelere erişim engeli karşısında temettü oranlarını artırmaktadırlar. Piyasalarda, geleneksel bankaların temettü ödemeleri hissedarların daha yüksek korunmasının sonucu olarak artmaktadır. Alt-sınıflandırma endeks sonuçları göstermiştir ki geleneksel bankalar daha yüksek azınlık yatırımcı korumasına, daha fazla yönetim kurulu üyeliği sorumluluğu ve daha fazla kamu aydınlatmasına göre temettü ödemelerini artırmaktadırlar.

Anahtar Kelimeler: temettü politikası; istikrar; vekâlet teorisi; sonuç; yerine; İslam bankaları; geleneksel bankalar 
To My Parents 


\section{ACKNOWLEDGMENT}

I would like to express my deepest gratitude and appreciation to my supervisor Prof. Dr. Cahit Adaoğlu for his patient continues guidance and encouragement throughout this study. His experience and knowledge have been an important help for my work.

I also would like to thank my co-supervisor Prof. Dr. Eralp Bektaş for his support and invaluable supervision to accomplish my thesis.

I would like to express my thanks to all the members of Department of Banking and Finance at Eastern Mediterranean University, especially Assoc. Prof. Dr. Nesrin Özataç and Assoc. Prof. Dr. Korhan Gökmenoğlu for their valuable support. I would also to thank all my close friends for their invaluable support.

Very special thanks go to my lovely parents for their endless support and encouragement in every stage of my studies. Without their support, it would not be possible to overcome the most difficult times during my studies. 


\section{TABLE OF CONTENTS}

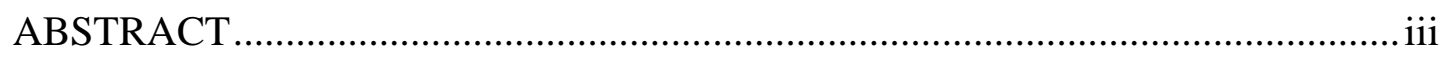

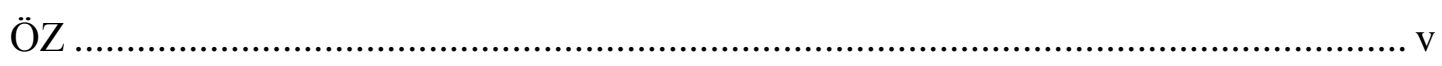

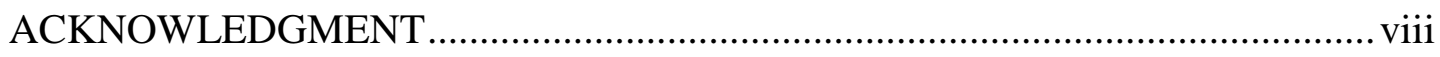

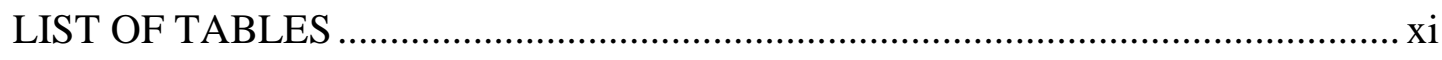

LIST OF FIGURES …...........................................................................

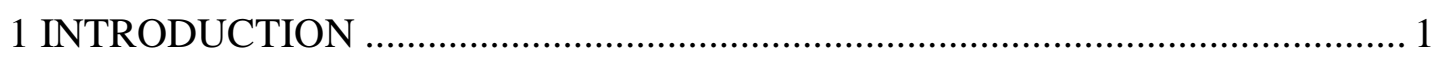

2 AGENCY THEORY AND DIVIDEND MODELS …........................................ 7

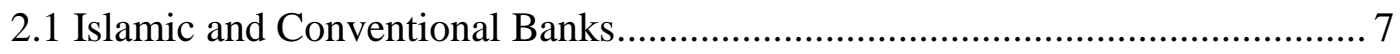

2.2 Agency Problems: Islamic and Conventional Banks .................................. 13

2.3 Dividend Models Implication: Substitute and Outcome.............................. 21

3 LITERATURE REVIEW .......................................................................... 23

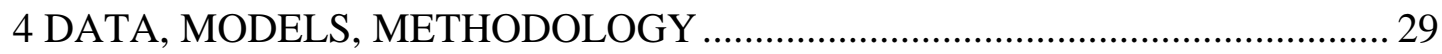

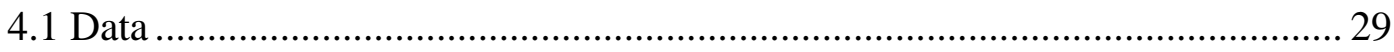

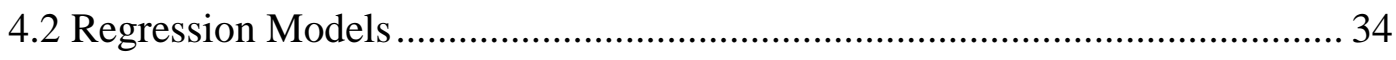

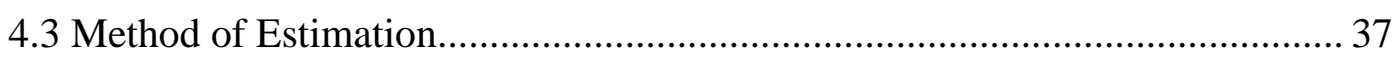

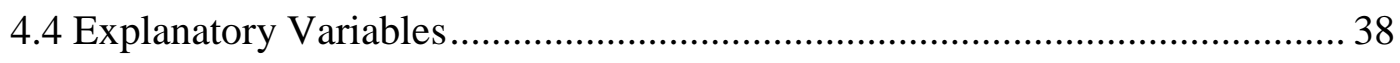

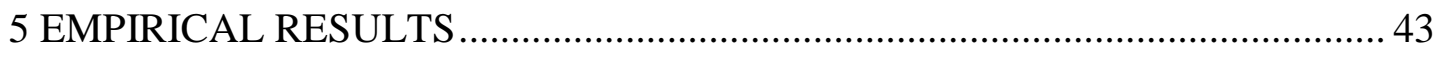

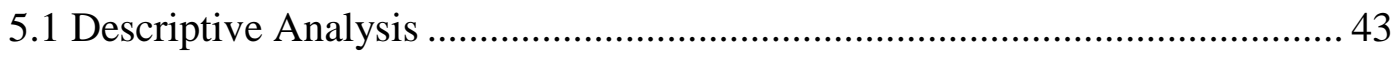

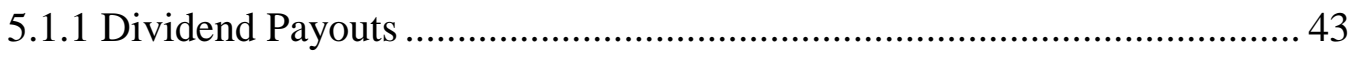

5.1.2 Dividend Behaviors to the Earning Changes / Signs ............................. 46

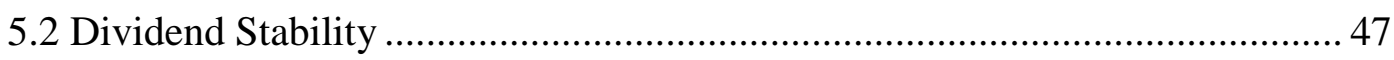

5.3 Univariate and Multivariate Analysis .......................................................... 51

5.3.1 Descriptive Variable Statistics .......................................................... 51 
5.3.2 Investor Protection and Interaction Effects

5.3.3 Investor Protection: Sub-Classification Index Effects ............................ 57

6 ROBUSTNESS CHECKS AND LIMITATIONS ................................................ 59

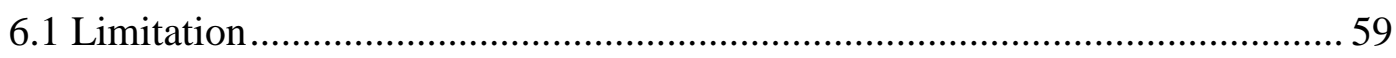

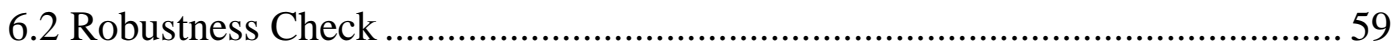

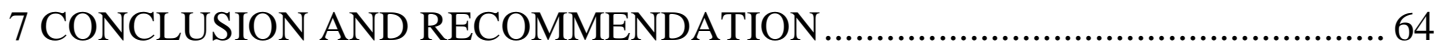

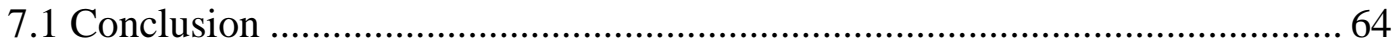

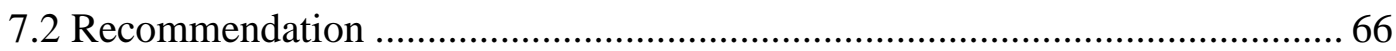

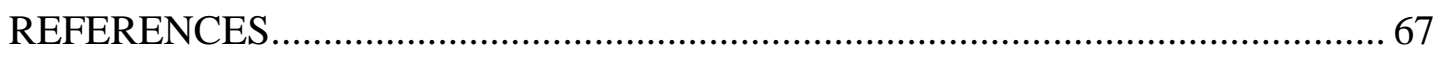

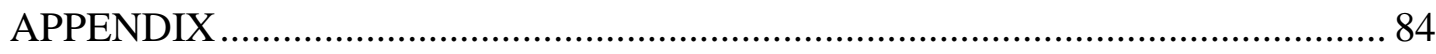

Appendix A: Abstract for the Publication of Thesis in the Journal Emerging Markets Review 85 


\section{LIST OF TABLES}

Table 1: Asset Size and Distribution of Islamic and Conventional Banks

Table 2: Protecting Minority Investors' Scores and Sub-classification indices 33

Table 3: Variable Descriptions and Expected Signs 42

Table 4: Descriptive Analysis: Dividend Payout Ratios (Overall and Pre- vs. PostSubprime Mortgage Crisis Periods) 45

Table 5: Dividend Behaviors to the Earning Changes / Signs..... 47

Table 6: Traditional Dividend Model Analysis: Islamic vs. Conventional Banks .... 50

Table 7: Descriptive Variable Statistics: Conventional Banks and Islamic Banks.... 52

Table 8: Dividend Payouts: Investor Protection and Growth 54

Table 9: Dividend Payouts: Investor Protection Sub-Classification Index Effects ... 58

Table 10: Dividend Payouts: Investor Protection and Growth 60

Table 11: Dividend Payouts: Investor Protection Sub-Classification Index Effects . 61 


\section{LIST OF FIGURES}

Figure 1: Mudaraba Contract Governance Structures in Islamic Banks.................... 16

Figure 2: Stylized Governance Structures of Conventional and Islamic Banks ........ 17

Figure 3: Islamic Banks Dividend Payouts (Dividend-to-earnings): Investor

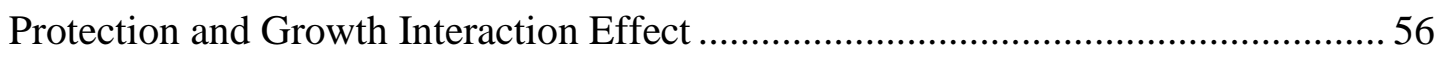

Figure 4: Conventional Banks Dividend Payouts (Dividend-to-earnings): Investor

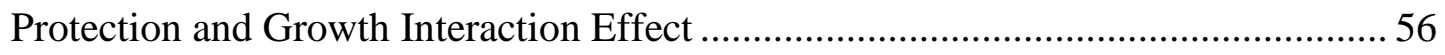

Figure 5: Islamic Banks Dividend Payouts (Dividend-to-cash flow): Investor Protection and Growth Interaction Effect 63

Figure 6: Conventional Banks Dividend Payouts (Dividend-to-cash flow): Investor

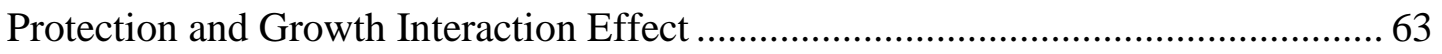

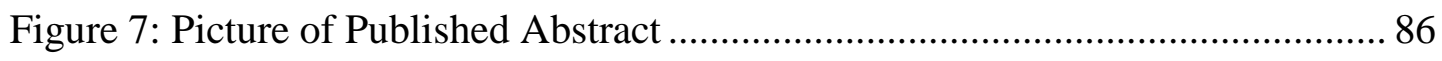




\section{Chapter 1}

\section{INTRODUCTION}

Over the last three decades, Islamic banks have grown in both size and number in Islamic and non-Islamic financial markets. The total assets of Islamic banks increased to $\$ 1.7$ trillion in 2013 with an annual growth rate of $17.6 \%$ since 2009 (Ernst and Young, 2013). Only one Islamic financial institution existed in 1975 (El Qorchi, 2005), and by 2014, 308 Islamic financial institutions were operating throughout the Organization of Islamic Cooperation (OIC) countries (World Bank, 2014). Unlike the traditional operations of conventional banks, Islamic banks operate differently and employ Sharia principles. Such operational and institutional differences have attracted the interest of numerous scholars, who have mainly focused on the business models, efficiency levels, asset quality levels, profitability and financial stability of Islamic banks. The relatively strong performance of Islamic banks during the contagious subprime mortgage crisis in 2008 has attracted particular research interest (Beck et al., 2013; Bourkhis and Nabi, 2013; Čihák and Hesse, 2010; Hasan and Dridi, 2010).

Dividend policy behaviors of financial companies, specifically those of conventional and Islamic banks, have not been explored adequately in the literature. I comparatively analyze Arab countries wherein there is no dividend tax and where a dual banking system is used. In these countries, investor protection is poor and Islamic banks strictly comply with Sharia principles. I examine countries included in the 
Morgan Stanley Capital International (MSCI) Arabian Market Index, which lists a broad range of countries, including Gulf Cooperation Council (GCC) and Middle East and North Africa (MENA) countries. GCC and MENA markets have contributed to the significant growth of global Islamic banking assets, with such assets reaching \$1.3 trillion in value as of 2011. This value was expected to grow beyond $\$ 2$ trillion in 2014 (Ernst and Young, 2012). I do not examine countries such as Turkey (Eastern Europe and Central Asia), Malaysia and Indonesia (East Asia and Pacific), which are typically included in Islamic finance studies. These countries are nonArabic, and Islamic banks in these countries do not strictly follow the Sharia principles (Chong and Liu, 2009). Moreover, investor protection is stronger in these countries (Doing Business, 2013).

In their prominent article, La Porta, Lopez-de-Silanes, Shleifer and Vishny (hereafter, LLSV) (2000) show that the likelihood of shareholder expropriation is comparatively higher in countries characterized by low levels of investor protection. LLSV state that managers of companies occupying low levels of investor protection environments are more likely to use free cash flows to their personal benefit and to expropriate the wealth of shareholders. They show that Common Law countries enjoy higher levels of investor protection and higher dividend payouts relative to those of Civil Law countries. In addition, they stress that agency problems play a significant role in dividend policies.

The substitute agency model of dividends presented by LLSV states that dividend policies are used as a substitute mechanism for alleviating relatively more pronounced agency problems and greater risks of expropriation by insiders. However, in countries with low levels of investor protection, companies use higher dividend pay- 
outs to convey that they care for and do not expropriate shareholders. In such countries, negative relationships between investor protection levels and dividend payouts are expected. This form of reputation building is even more critical for companies with growth opportunities. Therefore, in countries with low levels of investor protection, a positive relationship is expected between growth opportunities and dividend payouts (i.e., see Figure 2 in LLSV, 2000, p. 8). However, LLSV also stresses that such predictions are weak, as companies presenting growth opportunities may also be able to pay higher dividends owing to their higher levels of profitability.

According to LLSV's outcome agency model of dividends, dividends are the outcome of strong protection for shareholder rights, whereby shareholders can pressure insiders to pay out free cash flows. There is thus a positive relationship between investor protection levels and dividend payouts. Additionally, when shareholders are well protected, they accept lower dividends in cases of growth opportunity. However, in environments characterized by low levels of investor protection and concentrated ownership (i.e., see Bolbol and Omran, 2005; Omran et al., 2008) for ownership structures in Arab countries), shareholders, when confronted with expropriation problems, try to extract maximum cash flows from companies as soon as possible without even considering growth opportunities. In environments characterized by low levels of investor protection, the relationship between growth opportunities and dividend payouts is not clear and depends on levels of investor protection in a given country. LLSV describe this as a "testable implication" of the outcome agency model, but argue that a negative relationship between dividend payouts and growth opportunities with a relatively less steep slope for low protection countries exists (i.e., see Figure 1 in LLSV, 2000, p. 7). Several studies support the outcome agency 
model and show that dividend payouts are higher in strong corporate governance settings (Adjaoud and Ben-Amar, 2010; Jiraporn et al., 2011; Mitton, 2004).

LLSV also show that investor protection has a direct association with the extent of capital market development. Companies that operate in developed capital markets and have relatively more access to capital are more willing to pay out their earnings. This implies that dividend payouts are expected to be higher, more stable and less sensitive to the changes in earnings. In contrast, companies that operate in undeveloped capital markets have more incentives to retain their earnings and their dividend policies are more responsive to changes in earnings. Companies that operate in an environment of undeveloped capital markets and low investor protection are expected to have lower dividend payouts and less stable dividend policy (Aivazian et al., 2003; Lin, 2002). Claessens and Yurtoglu (2013) support the LLSV finding and show that in emerging markets, companies with better corporate governance benefit through greater access to financing, lower cost of capital and better performance. In line with previous finding, Djankov et al. (2008) also show that there is a positive relationship between capital market development and legal protection.

What about dividend policy behaviors in countries that follow Sharia law and that are characterized by typically low levels of investor protection? In this paper, I examine dividend stability and the effect of investor protection on dividend policies of Islamic and conventional banks operating in Arab markets. More specifically, I conduct a comparative analysis of agency problems for Islamic and conventional banks. I show that agency problems are more severe among Islamic banks operating in these countries. I examine dividend behaviors of Islamic and conventional banks in seven Arab countries namely Saudi Arabia, United Arabic Emirates (U.A.E.), Kuwait, Qatar, 
Bahrain, Jordan and Egypt from 2003-2012. In testing dividend stability levels and dividend payout models, I use general method of moments (GMM in- Sys) and Random- effects Tobit model, respectively. I use country-level "protecting minority investors" scores, growth opportunities, and interactions between growth opportunities and "protecting minority investors" scores. I explore differences in the dividend policies of conventional and Islamic banks by examining relationships between levels of investor protection and dividend payouts.

Focusing on the dividend stability results, I find that both conventional and Islamic banks follow stable dividend policies, but conventional banks have a more stable dividend policy. The dividend stability results also support the validity of the substitute model for Islamic banks and the validity of the outcome model for conventional banks. The findings support the association between investor protection, capital market development and dividend stability (Claessens and Yurtoglu, 2013; Djankov et al., 2008; LLSV, 2000). Results confirm that conventional banks, as a result of higher level of minority investor protection have greater accessibility to capital markets and have more willing to have stable dividend policies.

In poor minority investor protection settings, the empirical results also show that the substitute agency model of dividends explains the dividend payouts of Islamic banks. The empirical findings show that Islamic banks payout less dividends and use dividend policies as a substitute mechanism in order to mitigate relatively higher agency costs and establish a good reputation. For conventional banks, I find that the outcome agency model of dividends explains dividend payouts. Dividends are the outcome of strong protection for shareholder rights, whereby shareholders can pressure insiders to pay out free cash flows. Of the sub-classification indexes of "protecting minority 
investors" scores, the ease of shareholder suits index stands out among Islamic banks that support the substitute agency model of dividends. For conventional banks, the disclosure index and extent of director liability index stand out in support of the outcome agency model of dividends. The results suggest that Islamic banks increase dividends in response to weak minority investor protection, specifically the inability of shareholders to get corporate documents during litigation against firms. In contrast, Conventional banks increase dividends in response to stronger minority investor protection, specifically for the director liability and the amount of disclosure of related party transactions. Focusing on dividend determinants results, I find that profitability and size have statistically positive coefficients for both Islamic and conventional banks. Similarly, Leverage is statistically significant for both and asset compositions control variable is only significant for Islamic banks.

The remainder of the thesis is organized as follows. Chapter 2 contains an overview of Islamic and conventional banks, agency problems and dividend models implication. Chapter 3 explains the review of the literature on the concept of dividend policies. In chapter 4 , I describe the data, regression models, and methodologies used. In chapter 5, I present the empirical results. Chapter 6, I present robustness checks results and limitations. Chapter 7, concluding remarks and suggestions for further studies are presented. 


\section{Chapter 2}

\section{AGENCY THEORY AND DIVIDEND MODELS}

\subsection{Islamic and Conventional Banks}

Islamic banks have expanded in both size and numbers over the last three decades in Islamic and non-Islamic financial markets and they are becoming more competitive with their conventional counterparts. The total assets of Islamic banks increased to 1.7 trillion in 2013. Islamic banks employ Sharia principles and operate differently relative to conventional counterparts. Except for specific Muslim countries (e.g., Iran, Pakistan, Brunei, and Sudan) that their financial institutions operate only in accordance with Islamic principles, financial institutions in most of Muslim countries operate in compliance with Islamic and non-Islamic principles. In some non-Muslim countries, conventional financial institutions realize the value of Islamic financing and beginning to open separate Islamic departments (Islamic window) to offer Islamic financing services. However, in such countries where they have both Islamic and conventional financial institutions (dual financial system), Islamic banks are in a minority relative to conventional banks and the shares of Islamic banks in total domestic banking assets are comparatively lower than conventional banks.

According to the definition approved by the Organization of Islamic Conference (OIC), an "Islamic bank is a financial institution whose status, rules and procedures expressly state its commitment to principle of Islamic Sharia and to the abolishing of the receipt and payment of interest on any of its operations" (Ali and Sarkar, 1995, p. 
22). Ahmad and Hassan (2005) classify the fundamental differences between Islamic and conventional banks. They show in contrast to all interest basis of financial transactions in conventional banks, Usury and interest are banned in all Islamic banks' financial transactions and instead Islamic banks operate on profit and loss sharing basis. Islamic banks cannot use conventional financing techniques and instead they have to provide Sharia-compliant financing and investment modes. In addition, Islamic banks in line with Sharia principles offer return bearing investment accounts that are the same as interest bearing saving accounts in conventional banks. However, the relationship between Islamic depositors and bank management are not similar to the creditor- debtor relationship and Islamic banks share profits and losses with Islamic depositors.

In contrast to conventional banks that do not have zakat system, Islamic banks pay zakat on income for redistribution of income for the benefit of poor people. Islamic banks also have a Sharia boards as an additional governance layer that they comply all practices and activities of Islamic banks with Sharia principles. Sharia boards together with regular boards of directors and executive lead to Islamic banks have multi-layer governance structure relative to single-layer governance structure in conventional banks (Mollah and Zaman, 2015). I explain Sharia principles and financing modes, types of accounts, and Sharia boards in more details, as they are three main structural differences between two types of banks. 
Three Sharia principles differentiate the operational activities of Islamic banks from those of other banks. These principles include the prohibition of interest (Riba); the prohibition on the financing of activities such as the trade of alcoholic beverages (haram); and the prohibition of gambling in business activities (Gharar) (Siddiqi, 1985). In Islamic law, Riba can be classified as Riba al-Qarud (loans) and Riba alВиуи (trade). In further classification, Riba al-Buyu has two different forms namely Riba al-Nisa and Riba al-Fadl. The former includes the non-simultaneous exchange of equal quantities and qualities of the identical commodity, whilst the latter involves an exchange of unequal quantities or qualities of the identical commodity at the same time (Algaoud and Lewis, 2007, p.43). In addition to these principles, profit and loss sharing (PLS) and asset-backed operational activities constitute distinctive features of Islamic banks. Islamic banks must develop alternative financing approaches by using return-bearing contracts. Hence, Islamic banks offer different modes of financing, namely PLS-based Mudaraba and Musharaka and markup-based financing techniques, which are mainly Murabaha, Ijara, Salam, Istisna, and Sukuk.

Musharaka refers to a partnership or joint business venture whereby Islamic banks and entrepreneurs (i.e., borrower in a conventional bank setting) jointly invest and manage investments. In Musharaka financing, profits and losses are shared based on a pre-agreed ratio and proportion of capital contribution. While all parties have investment management participation rights, they are not required to participate. In Mudaraba financing, only Islamic banks provide funds while entrepreneurs put in efforts and control management. On the asset side, Islamic banks and entrepreneurs share investment profits on the basis of a predetermined profit sharing ratio, and on the liability side, a bank follows an agreement with Islamic depositors to share prof- 
its accruing to the bank, while depositors bear all of the losses (Shanmugam and Zahari, 2009).

Murabaha contracts are similar to conventional interest-based lending operations. Islamic bank management teams agree to purchase assets or goods for a client and then resell them at a pre-determined price that includes a negotiated profit margin and the original cost. Ijara (i.e., leasing) refers to an agreement with a client whereby an Islamic bank purchases and leases an asset or equipment for a fixed lease fee and for a certain period of time. Salam (i.e., advance purchase) involves the purchase of a specified good with payments made in the future. Such payments are typically used to finance agricultural production. Istisna (i.e., commissioned manufacture) refers to a contract wherein one side buys goods while the other side uses the same goods for manufacturing based on agreed specifications. Islamic banks frequently use Istisna methods to finance construction and manufacturing investments. Sukuk (i.e., participation securities) refers to Islamic bonds, and in contrast to conventional bonds wherein the issuer is obligated to pay interest and principal costs to bond holders, an underlying asset should be exchanged by Sukuk methods (Mirakhor and Zaidi, 2007).

Deposits to Islamic banks can be broadly classified into current or demand deposit accounts and profit sharing investment accounts (Grais and Pellegrini, 2006; Greuning and Iqbal, 2008). Islamic current or demand deposit accounts are similar to those of conventional banks and are based on the Amanah and Wadiah principle (Greuning and Iqbal, 2008). Under Amanah and Wadiah arrangements, Islamic banks collect interest-free deposits and treat deposits either as a trust (Amanah) or for safekeeping (Wadiah). Current account deposits can also be based on the Qard principle, whereby banks use current account funds as non-interest loans for their investments. In all 
cases, Islamic banks can obtain authorization to use depositor funds for any reason in compliance with Sharia principles and to pay no profit shares or fixed interest to the depositors (Greuning and Iqbal, 2008). The only exception concerns donations (Hi$b a$ ), which are distributed at a bank's discretion. As current account deposits are deemed bank obligations, any losses or risks resulting from the use of current account deposits for operational activities such as Mudaraba are not shared by such depositors (Grais and Pellegrini, 2006). Therefore, any profits or losses resulting from the use of such deposits only accrue to the bank. Current account depositors have no claim in profits and assume no obligations with respect to losses.

Islamic banks also offer profit sharing investment accounts based on a Mudaraba contract (i.e., partnership-basis) that can be considered as their main distinguishing characteristic (Archer and Karim, 2009). In contrast to interest bearing saving accounts in conventional banks, investment accounts are based on profit and loss sharing. Investment accounts also offer based on Wakala contract that bank as a wakeel or agent receives a management flat fee for managing the customers' funds. On average, investment account holders supply $80 \%$ of Islamic bank funding sources (Sundararajan, 2007, p. 47). Investment account holders, who are considered quasiequity holders, share profits and losses under the Mudaraba contract for a specified maturity period. However, investment account holders cannot withdraw before reaching maturity, and they do not participate in bank management governance or in the direct monitoring of entrepreneurs.

Investment accounts are divided into two categories, namely unrestricted investment accounts and restricted investment accounts (Greuning and Iqbal, 2008). In restrict$e d$ investment accounts, Islamic banks act as fund managers and must invest in pro- 
jects that are specified by Islamic depositors, whereas depositors of unrestricted investment accounts allow Islamic bank management teams to invest in any Shariacompliant investment. Islamic banks place these funds in Sharia-compliant investment pools and distribute generated profits or losses based on a predetermined profit and loss sharing ratio. However, according to the Mudarabah contract, investment account holders do not bear risks associated with poor investment portfolio performance when losses are due to bank management misconduct (Archer et al., 1998; Grais and Pellegrini, 2006). The Accounting and Auditing Organization for Islamic Financial Institutions (AAOIFI, 2008) classifies unrestricted investment accounts (i.e., quasi-equity holders) as a separate entry point between liability and owner equity on the balance sheet of Islamic banks.

Islamic banks also have an additional layer of governance, namely Sharia boards that have both advisory and supervisory responsibilities. Sharia boards have a significant role related to the relationship between bank management, depositors, and shareholders (Chaowdhury, 2004; Nienhaus, 2007). Sharia boards establish Sharia supervisory boards (SSB) to ensure all levels of financial transactions and practices comply with Islamic principles and Quran (Algaoud and Lewis, 1999; Nadwi, 2012). In addition, Sharia supervisory boards constraint Islamic banks' managements and board of directors from involving in aggregate loans and taking risky activities and investments (Mollah and Zaman, 2015). The boards for Sharia compliance cooperate with high-rank scholars who are eligible to issue Fatawa. They perform independently as Sharia advisors and auditors to the Islamic banks. Sharia supervisory boards also have a supervisory role for Sharia compliance of investment and financing products and to calculate zakat payments. Despite international Sharia boards (e.g., Accounting and Auditing Organization for Islamic Financial Institution (AAOIFI)) 
that they publish Sharia standards, there are national Sharia boards in specific Muslim countries such as Malaysia, Pakistan, Sudan and Indonesia that have the authority on Sharia surveillance framework and policy.

\subsection{Agency Problems: Islamic and Conventional Banks}

I focus on agency relationships in both conventional and Islamic banks and carry out a comparative analysis. In both Islamic and conventional banks, traditional agency problems exist due to the separation between ownership and management. However, in light of more effective competition and deposit insurance system in the conventional banking sector and unique institutional settings of Islamic banks, potential agency problems are not the same for these two types of banks. Islamic banks are relatively confronted with more serious principle-agent problems and experience more agency problems. For instance, the main regulatory problem associated with using investment accounts lies in the fact that holders do not meet legal definitions of deposits (Archer and Karim, 2009; Nienhaus, 2007). Islamic banks do not guarantee the depositor's principal or returns. Depositors of Sharia-compliant accounts (i.e., investment accounts) have a conditional claim to the full repayment of principles and are more exposed to return risks resulting from profit and loss fluctuations. Despite positive risk sharing benefits enjoyed by Islamic bank management teams, depositors of investment accounts, who are classified as quasi-equity holders, are exposed to various risks, and especially to those associated with PLS contracts (i.e., Mudaraba and Musharaka) (Chapra, 2007, p. 338).

In comparison to conventional banks, Islamic banks occupy unique institutional settings that lead to serious adverse selection and moral hazard problems in both asset and liability sections of the balance sheet (Nienhaus, 2007; Visser, 2009). Adverse 
selection problems emerge from Islamic bank liabilities between Islamic depositors (i.e., especially investment account holders) and Islamic bank management teams. However, due to features of Mudaraba contracts, this issue is more serious for investment account holders, and especially for unrestricted investment account holders. Investment account holders do not know the magnitude of risks taken by Mudarib (manager or entrepreneur) and do not have the power to determine profit sharing ratios (Astrom, 2011).

Governance structures for Mudaraba contracts are shown in Figure 1 (see, Li et al., 2012, p. 51). Islamic banks management teams in Mudaraba contracts place the funds of unrestricted investment accounts holders and shareholders in the same Sharia-compliant investment pools and they can easily increase shareholder wealth levels at the expense of investment account holders. Consequently, Depositors of unrestricted investment account holders bear the same risks as Islamic bank shareholders. Especially as shown in Figure 1, the extent of investment account holder expropriation is accentuated, as investment account holders vis-à-vis equity holders of conventional banks do not have governance rights to control a bank's managerial decisions, and they are also not in a position to enforce monitoring measures (Archer et al., 1998).

Furthermore, bank management in Mudaraba contracts does not have governance right to monitor entrepreneurs investment activities. In contrast to conventional banks that borrowers pay a predetermined interest rate, entrepreneurs using Musharaka and Mudaraba financing methods (hybrid equity and debt financing) have more incentives for using quasi-equity holder (i.e., investment account holders) funds for personal benefits and perks (Bacha, 1995, p. 40). Mudaraba financing is a 
hybrid financing instrument, as it is not a form of equity or debt. For an entrepreneur (Mudarib), Mudaraba financing is similar to conventional equity financing as; a) there are no "fixed" annual payments; b) Islamic banks cannot take legal action when losses occur; c) similar to dividends, payments must be paid if and only if profits result; d) unlike financial costs incurred as a result of debt financing use, Mudaraba financing does not increase a firm's degree of risk.

In addition, Mudaraba financing is similar to conventional debt financing as for Mudarib, it represents a "fixed" and "terminable" claim to repay principal and accrued profits to an Islamic bank (Bacha, 1995). Entrepreneurs can easily increase accrued costs, in turn decreasing profits. However, the decline in their share of profits is likely to be less than the increase in their personal benefits and perks (Bacha, 1995). Under profit and loss sharing (PLS) mechanisms, borrowers are presented with more incentives to under-report profits and over-report expenses (Sarker, 1999). Relative to borrowers from conventional banks, entrepreneurs who use PLS (Mudaraba) financing have less reason to do their utmost to maximize shared profits (Visser, 2009). Consequently, the extent of investment account holder expropriation is accentuated and investment account holders bear both direct and indirect agency costs (Beck et al., 2013). Additionally, as Mudaraba financing is a hybrid form of equity and debt financing, overall agency problems associated with asset portfolios of Islamic banks are more severe (Bacha, 1995). 


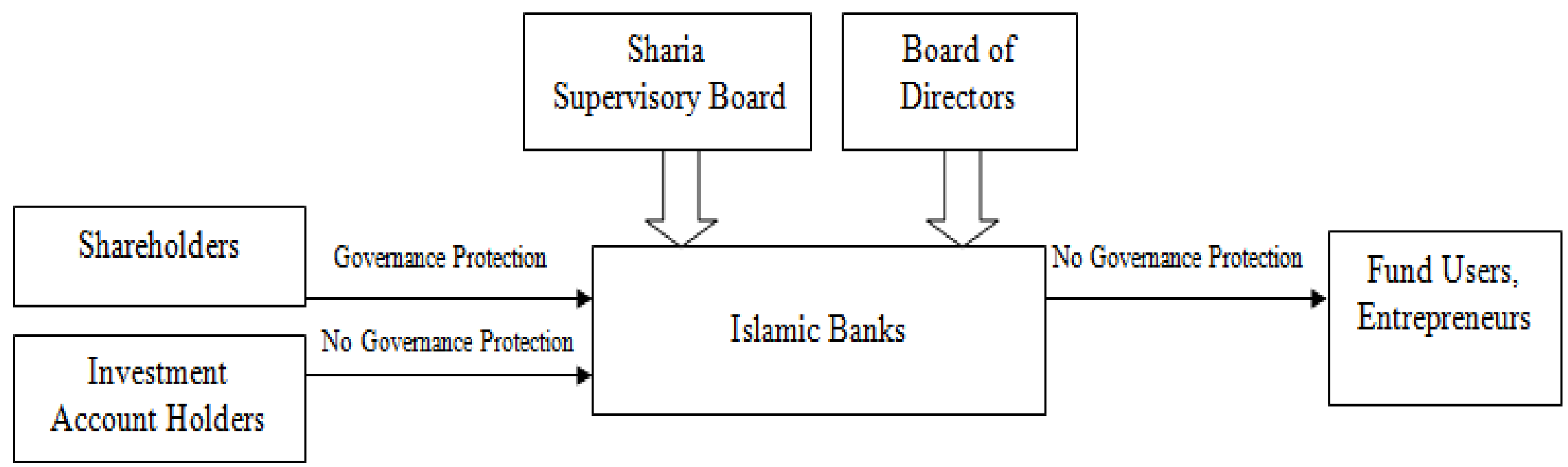

Figure 1: Mudaraba Contract Governance Structures in Islamic Banks 
Figure 2 presents the both conventional and Islamic banks' governance structures (Nienhaus, 2007, p. 129). Levels of competition in a sector form an integral part of governance structures for both types of banks. In many Islamic countries where Islamic and conventional financial institutions co-exist, conventional banks typically dominate the banking market, and benchmark returns typically represent the rate of returns offered by conventional banks. Moreover, competition between conventional banks is higher, and depositors are well protected by deposit insurance (Islamic Financial Services Board, 2010; Nienhaus, 2007). In light of more effective competition and deposit insurance in the conventional banking sector, potential agency conflicts between depositors, bank managers, and shareholders are likely to be less severe relative to those of the Islamic banking sector.

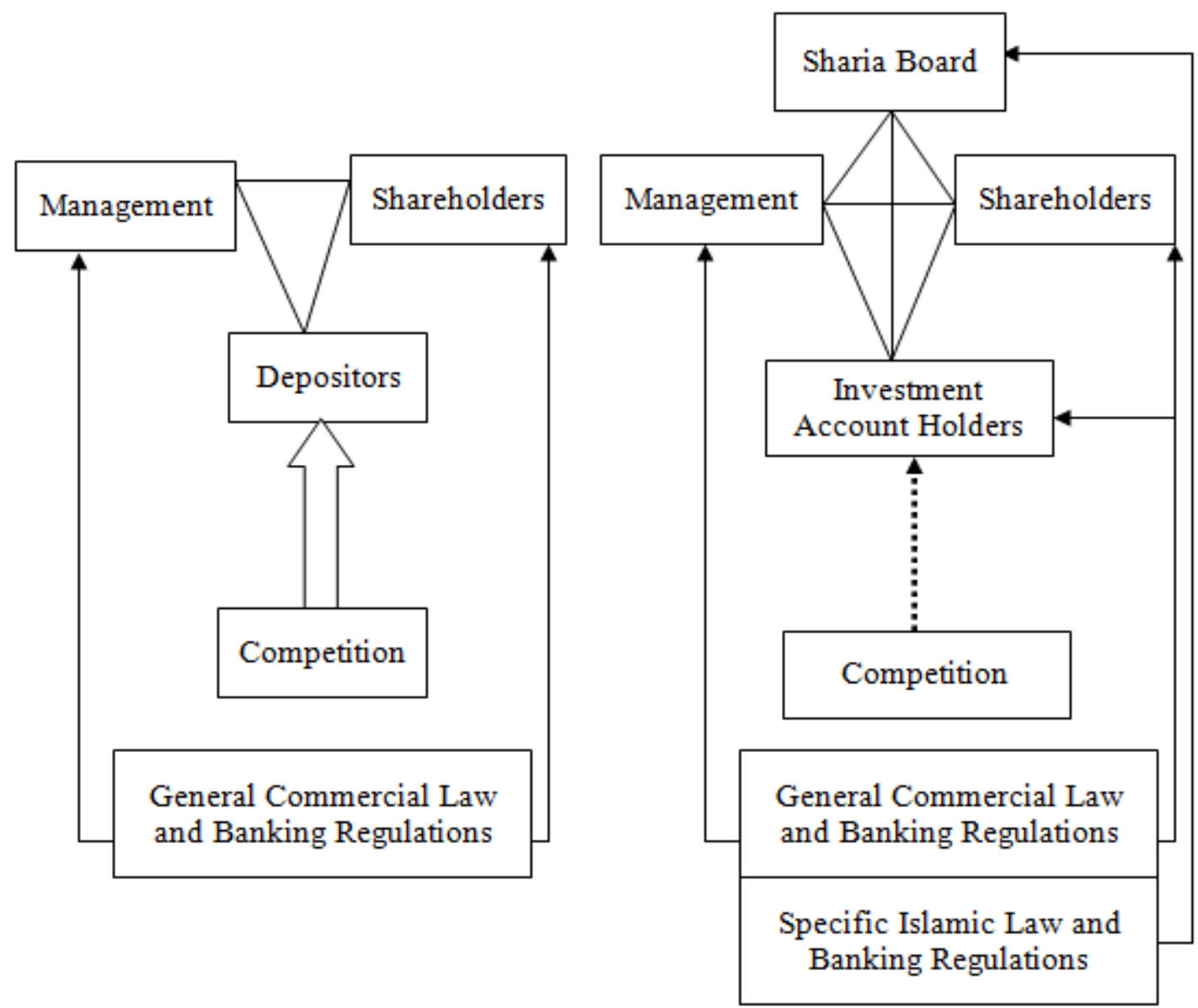

Figure 2: Stylized Governance Structures of Conventional and Islamic Banks 
Furthermore, Islamic bank managers typically set profit sharing ratios according to the conventional banking sector's benchmark rate of return, which is lower than the risk-identical rate of return for conventional banks. By increasing their profit share, both Islamic bank managers and shareholders can exploit investment account holders who may not be fully aware of potential risks and who do not have governance tools to monitor bank management teams and entrepreneurs directly. Consequently, the fundamental conflict lies in the determination of profit-loss sharing ratios between depositors, bank management teams and shareholders (Nienhaus, 2007).

Especially, this conflict is more severe for Islamic banks operating in an environment that is characterized by low levels of investor protection and concentrated ownership structure. In a weak shareholder protection setting, controlling shareholders has more incentive and power to monitor bank management teams and take recourse against any potential forms of expropriation (La Porta et al., 1998; La Porta et al., 1999; Shleifer and Vishny, 1986). However, in addition to shareholders and bank management teams, Islamic banks have one more important quasi-shareholder: the investment account holder. As investment account holders have no governance rights to control manager actions, they mainly rely on "vicarious monitoring" by shareholders (Archer et al., 1998). However, this monitoring can only be effective when the interests of shareholders and investment account holders converge.

In countries with low level of investor protection and concentrated ownership structures (e.g., see Srairi (2013) for ownership concentration evidence on Islamic banks), the convergence of interest between controlling shareholders and investment account holders are less likely to occur. For instance, controlling shareholders have more incentives to make risky investments though PLS (Mudaraba) contracts, as invest- 
ment account holders and shareholders are exposed to similar risks (Shanmugam and Zahari, 2009). Greuning and Iqbal (2008) also show that shareholder-controlled management teams and boards may favor and protect shareholder investments at the expense of unrestricted investment account holders through the mechanism of pooling shareholder and investment funds. Bank management teams by commingling depositor and shareholder funds and invest in the same portfolio can easily increase shareholder wealth levels at the expense of investment account holders, especially unrestricted investment account holders who have no governance rights in determining profit loss ratios and who at the same time bear the same risks as Islamic bank shareholders (Bacha, 1995; Karim and Archer, 2002). Taking into account the concentrated ownership structures and unique governance structures of Islamic banks, both bank management teams and controlling shareholders have more incentives to expropriate investment account holder funds. In line with these arguments, Islamic banks are confronted with more significant adverse selection and moral hazard costs on both liability and asset sides of the balance sheet (Astrom, 2011; Nienhaus, 2007; Visser, 2009).

Moreover, the ban on Riba renders liquidity management difficult for Islamic banks and precludes operation in the conventional money market (Visser, 2009). Islamic banks have limited access to Sharia-compliant instruments for managing liquidity, and Sharia compatible money and interbank markets do not exist (Greuning and Iqbal, 2008; Islamic Financial Services Board, 2010). For the purpose of liquidity management and operational limitation, Islamic banks end up holding significant amounts of excess cash or other liquid assets with low rates of return. As Islamic banks are at a comparative disadvantage in terms of liquidity management, they must rely on return smoothing techniques (e.g., the profit equalization reserve (PER), the 
investment risk reserve (IRR), the Mudarib share of profits, and the commingling of funds) (Greuning and Iqbal, 2008; Islamic Financial Services Board, 2010; Nienhaus, 2007). According to the Islamic Financial Services Board (2010), the smoothing return techniques are typically used by Islamic financial services industry (IFSI). However, applying each return smoothing technique without appropriate disclosure can exacerbate unique agency problems among all parties involved.

For instance, while the PER belongs to both investment account holders and shareholders, bank management teams to determine whether to use the profit equalization reserve to smooth the deposit rate of return or to increase dividend payments to bank shareholders. The commingling of funds technique (i.e., current account and investment account deposits or/and shareholder funds) can favor investment account holders and shareholders when an Islamic bank can accumulate above-average funds from current accounts with no returns (Nienhaus, 2007). However, the commingling of funds technique cannot be monitored and assessed by investment account holders due to the very limited information published in official statements (Nienhaus, 2007). Similarly, the existence of the IRR, which is only financed from attributable profits of investment account holders, may encourage Islamic bank management teams to engage in excessive risk-taking at the expense of investment account holders (Islamic Financial Services Board, 2010). Consequently, return smoothing techniques without appropriate disclosure can exacerbate agency problems among all parties involved, and particularly among unrestricted investment account holders, bank management teams, and shareholders. At the same time, in using return smoothing techniques, Islamic banks can avoid investment account deposit fluctuations. Return stability is especially critical for unrestricted investment account holders, who are considered Sharia-compliant alternatives for deposits in conventional 
banks. Consequently, return stability can mitigate withdrawal risks (Nienhaus, 2007). In the long run, return smoothing techniques can hold rates of return for investment account holders at a level in line with the benchmark interest rates of conventional banks. However, this might not be beneficial for investment account holders who bear higher risks compared to depositors in conventional banks.

\subsection{Dividend Models Implication: Substitute and Outcome}

Islamic banks are presented with relatively higher agency costs in countries with both types of banks (dual banking system) in their financial systems. Especially in such Arab countries with low levels of investor protection and concentrated ownership, controlling shareholders of Islamic banks have more incentives to make risky investments and increase shareholder's wealth at the expense of quasi-equity holders. In these markets, Islamic banks are more willing to use free cash flow for their personal benefits and risks of expropriation by insiders is high. In line with dividend payout model predictions, Islamic banks are more likely to set their dividend policies in line with substitute agency model of dividends. Islamic banks operating in these countries can potentially alleviate the relatively higher agency problems and expropriation concerns of minority shareholders by paying out dividends. Islamic banks are more likely to use dividend policies as a reputation building mechanism for external financing. Astrom (2011) state that Islamic banks can indicate their degree of quality by using dividend policies as a mechanism.

Comparatively, conventional banks have less need to use dividend policies as a reputation building mechanism for external financing, and as an outcome of strong shareholder protection they payout higher dividends. In line with dividend payout model predictions, the substitute agency model of dividends may not hold for conventional 
banks operating in these countries. Conventional banks may not set their dividend policies according to the substitute model, but may instead set them according to the outcome model. Conventional banks have relatively lower agency costs and are more likely to be subject to international banking standards. Conventional banks manage more effective deposit insurance systems and are more likely to adopt international accounting standards. Moreover, relative to Islamic banks, conventional banks can enjoy greater access to external finance, especially from international capital markets. Unlike in Islamic banks, where Sharia principles restrict the financial instruments they can use, conventional banks can fully utilize all financial instruments in their domestic and international markets.

In countries characterized by low levels of investor protection, concentrated ownership, and Sharia law, the following empirical analysis will shed light on the following questions: first, which agency model of dividends can explain dividend policy behaviors of Islamic and conventional banks? Second, which type of banks does have relatively more stable dividend policies and higher dividend payouts? 


\section{Chapter 3}

\section{LITERATURE REVIEW}

Dividend policy is one of the most researched topics in modern corporate finance, but it is still considered as a puzzle (Black, 1976; Allen and Michaely, 2003). Lintner (1956), who was the pioneer in studying the determinants of dividend policy, concluded that past dividend payments and earnings are the main significant determinants of dividend policy. According to the Lintner's results, managers adjust dividends relatively infrequently and strive to maintain stable dividend payments. This practice of maintaining relatively constant dividends is called dividend smoothing. Managers of companies increase dividend payments only when they expect the future earnings has a sustainable positive growth. Fama and Babiak (1968) by developing and reformulated Lintner's model, they confirm the Lintner's results and show that managers of companies are willing to pay stable dividends. Many studies have empirically tested and tried to build on the Lintner's dividend model mainly for U.S. non-financial firms (Darling, 1957; Fama and Babiak, 1968; Baker et al., 1985; Fama and French, 1997; DeAngelo and DeAngelo., 1990) and for emerging markets (Glen et al., 1995, Adaoglu, 2000, Aivazian et al., 2003). Except for some studies (Adaoglu, 2000; Ahmed and Javid, 2009; Aivazian et al., 2003; Glen et al., 1995), the majorities of studies confirm the validity of Lintner's results and show that their dividend policies are less responsive to changes in earnings. 
Furthermore, Miller and Modigliani (1961) indicated in a perfect market conditions dividend decision has no impact on the equity holder's wealth or firm value. However, the presence of market imperfections, in reality, has expanded the development of dividend determinants and theories. Baker (2009) classified determinants of dividend choices by firm characteristics, market characteristics, and substitute forms of payout. By relaxing market conditions, the findings by (Poterba and Summers, 1984; Lie and Lie, 1999; Perez-Gonzalez, 2003) confirmed tax policy has an effect on dividend choices. In addition, (Glen et al., 1995; Al-Kuwari, 2009) found tax policy, stock market volatility and information asymmetry are major factors that lead to making differentiation of dividend's decision between emerging and developed markets.

Focusing on ownership structure, the findings by (Easterbrook, 1984; Jensen and Meckling, 1976; Rozeff, 1982) proposed the agency theory explanation of why firms should pay dividends. They show that agency problems will occur by separation of management and ownership, and the differences in managerial and shareholder priorities. They show that company management has more willing to use free cash flows for personal benefits and perks when interest between management and ownership diverge. Easterbrook (1984) emphasized that dividend payment can alleviate agency problems between shareholders, management, and owners by reducing the free cash flows. Jensen (1986) also showed that managers have a potential to use free cash to undertake risky projects and invest in projects with negative NPV with the aim of increasing their personal utility. He stressed that managers use dividend payments, as a device to reduce free cash flows and over investment projects.

In line with these arguments, there are some studies that examine the relationship between ownership structure and dividend policy. Trojanowski and Renneboog 
(2007) and Zameer et al. (2013) show that dispersed ownership structure is positively associated with dividend payout. Other studies show ownership concentration is negatively associated with dividends payout (Gugler and Yurtoglu, 2003; Trojanowski and Renneboog, 2005; Khan, 2006). Focusing on the banking sector, Wen and Jia (2010) show banking holding companies with greater ownership dispersion use dividends to reduce the agency problems. Zameer et al. (2013) show ownership structure has a positive impact on banks payout ratio in Pakistan. Daradkah and Ajlouni (2013) indicate compositions of blockholder are matter and banks with more institutional concentrated ownership have higher dividend payout ratio. Ben Slama Zouari and Boulila Taktak (2014) show that the overall ownership concentration does not affect the Islamic bank performance, but family and government concentrated ownership structure positively affect the Islamic banks.

In their prominent article, La Porta, Lopez-de-Silanes, Shleiefer and Vishny (2000) show that the extent of agency conflicts and shareholder expropriation depends on investor protection. Accordingly, LLSV (2000) state two agency models of dividends, namely substitute agency model of dividends and outcome agency model of dividends. The outcome model predicts that in countries with strong shareholders protection dividend payout ratios are higher, whereas the substitute model predicts the opposite. They show that the likelihood of shareholder expropriation is comparatively higher in countries characterized by low levels of investor protection. In such an environment, managers of companies are more likely to use free cash flows for their personal benefit and to payout less dividends. LLSV (2000) state that in low levels of investor protection countries, dividend policies follow with substitute agency model of dividends and are used as a substitute mechanism for alleviating relatively more pronounced agency problems. However, in countries characterized by 
high levels of investor protection dividend policies set in line with the outcome agency model of dividends and are used as an outcome of strong protection for shareholder rights. In addition, they indicate legal origin have an association with the extent of agency problems. Law Common countries have relatively higher levels of investor protection to those of Civil Law countries. In Common Law countries, shareholders experience less agency problems and higher dividend payouts. In contrast, shareholders in Civil Law countries experience higher agency problems and less dividend payouts.

Several studies examine the effect of firm-level investor protection on dividend policy behavior. In a study by Kowalewski et al. (2008), they pointed out that corporate governance has a positive relationship with the dividend payout. In contrast, John and Knyazeva (2006) show under weak governance condition, shareholders are more likely to receive more dividends. Garay and González (2008) and Chong and Lópezde-Silanes (2006) confirmed the existence of an association between corporate governance quality and dividend payouts. The findings (Adjaoud and Ben-Amar; 2010; Jiraporn et al.; 2011; Mitton, 2004) show that companies set dividend policies in line with outcome agency model of dividends and show that dividend payouts are higher in strong corporate governance settings. They show that shareholder protection should explain at both country-level investor protection and firm-level corporate governance and these serve as substitutes or complements.

Focusing on dividend payout determinants in the banking industry, Gupta and Walker (1975) studied dividend payment determinants of 980 banks over the period 1965 1968, and found that profits, total asset growth, and liquidity are the significant determinants. Keen (1978) also attempted to examine the effect of dividend cuts on 
deposits, share price and operating performance for 16 banks over the period 19741977. His findings showed that deposits and share price behavior do not exhibit significant changes after the dividend cut announcement. In addition, Mayne (1980) examined the dividend payment determinants using a large sample of more than 12,000 banks. His finding showed that dividend payment decision is affected by the total assets, equity, the income before security gains and holding company affiliation. In a further research by Kennedy and Scott (1984), they found dividend payment decision is related to firm size, the number of shares outstanding and various measures of geographical restrictions.

Similarly, Kennedy and Nunnally (1986) show the dividend payout ratio is explained by the dividend history and the price-earnings ratio. In another study by MercadoMendez and Willy (1995), dividend policy can be used as a substitute mechanism to decrease the agency costs. Casey and Dickens (2000) show that investment opportunities and agency problems are the main determinants of dividend policy in the banking sector. Dickens et al. (2002) show the negative effects of information signaling, investment opportunities, ownership and risk, and the positive effects of size and dividend history on the dividend payout ratio. Nnadi and Akpomi (2005) identified current profits, financial leverage, past dividends and legal restrictions are the major dividend determinants in the Nigerian banking industry. Bodla et al. (2007) found current profits and past dividends are the main factors behind dividend policy for Indian banking industry. Lee (2009) show that the dividend payout ratio is positively related to the profitability and size of bank in the Korean banking industry, and the dividend policy is closely associated with the bank riskiness. Imran et al. (2013) show that earning per share, last year's dividend, capital ratio, and size positively and cash flow negatively affects the dividend payout ratio in Pakistan. 
In addition to previous studies, numerous scholars have carried out comparative studies between Islamic and conventional banks. Especially, the relatively strong performance of Islamic banks during the contagious subprime mortgage crisis in 2008 has attracted particular research interest (Beck et al., 2013; Bourkhis and Nabi, 2013; Cihak and Hesse, 2010; Hasan and Dridi, 2010). In comparative studies, Hasan and Dridi (2010) and Srairi (2010) show that Islamic banks are relatively more efficient and have superior performance during the financial crisis. Beck et al. (2013) and Hassan and Bashir (2003) show Islamic banks during the financial crisis is better capitalized and they have higher asset quality and better capital asset ratios relative to conventional banks. In another empirical study, Cihak and Hesse (2010) show that in small Islamic banking system, Islamic banks are financially more stable than conventional banks. However, this finding is not valid in large Islamic banking system and they are financially less stable than conventional banks. Khan (1986) show that Islamic banks are able to share the financial risks with Islamic depositors and diminish the adverse effect of financial shocks when they use profit- loss sharing and assetback principles in their financial activities. 


\section{Chapter 4}

\section{DATA, MODELS, METHODOLOGY}

\subsection{Data}

I first present the countries that are covered by the MSCI Arabian Market Index ${ }^{1}$ (2015), which captures the stock performance of large and mid-cap companies across 11 Arab Markets countries, including Bahrain, Egypt, Qatar, the United Arabic Emirates, Jordan, Kuwait, Lebanon, Morocco, Oman, Saudi Arabia and Tunisia. This index offers broad coverage, including all Gulf Corporation Council (GCC) countries and some Middle East North Africa (MENA) countries such as Jordan, Egypt, Morocco, Tunisia, and Lebanon. GCC and MENA (i.e., excluding GCC countries in MENA) countries have $38.22 \%$ and $42.93 \%$ global share of total Islamic banking assets respectively. ${ }^{2}$ In conducting an accurate comparative analysis, I selected those countries with dual banking systems. I exclude Morocco, Tunisia, and Lebanon, as these countries do not employ dual banking systems. I also exclude Oman from my sample, as I do not have access to data on Islamic banks in Oman.

In classifying banks as Islamic or conventional, I used Thomson Reuters Worldscope business descriptions and Thomson Reuters Zawya business descriptions. The Zawya index strictly focuses on Islamic finance institutions. I collected financial data from the Thomson Reuters Worldscope database. In a few cases, I collected data by hand

\footnotetext{
${ }^{1}$ http://www.msci.com/resources/factsheets/index_fact_sheet/msci-arabian-markets-index.pdf

${ }^{2}$ http://www.ifsb.org/docs/2015_IFSB\%20Islamic\%20Financial\%20Services\%20Industry\%20Stability\%20Repor t\%202015_final.pdf
} 
from annual reports, which are available on bank websites. I restrict my study to the 2003-2012 periods, as data from the Thomson Reuters Worldscope and Zawya databases and from the annual reports of Islamic banks are not comprehensive prior to 2003.

Table 1 shows the countries examined in my sample and the distribution of Islamic and conventional banks. The sample includes seven countries that include 27 publicly traded Islamic banks (i.e., $79.41 \%$ of the total number of Islamic banks in these countries) and 52 publicly traded conventional banks (i.e., $74.28 \%$ of the total number of conventional banks). For some of the sampled countries, publicly traded Islamic or conventional banks include all Islamic or conventional banks (e.g., Saudi Arabia, U.A.E., Kuwait and Egypt). Table 1 also shows the market size of Islamic banks at country and global level. At the global level, the total share of sample countries is $67.52 \%$ of total global Islamic assets of dual banking system. In my sample, Saudi Arabia by $31.59 \%$ and Jordan by $0.83 \%$ has the highest and lowest percentage share of global Islamic banking assets. At the country level, the share of Islamic banks in total domestic banking assets varies between $51.30 \%$ and $6.70 \%$. Saudi Arabia and Kuwait have the highest and Egypt and Jordan have the lowest percentage of domestic Islamic banking assets. 
Table 1: Asset Size and Distribution of Islamic and Conventional Banks (2003-2012)

\begin{tabular}{|c|c|c|c|c|c|c|}
\hline \multirow[b]{2}{*}{$\begin{array}{l}\text { Sample } \\
\text { Countries }\end{array}$} & \multirow{2}{*}{$\begin{array}{c}\text { Share of } \\
\text { Islamic } \\
\text { Banks } \\
\text { in Total } \\
\text { Domestic } \\
\text { Banking } \\
\text { Assets (\%) }\end{array}$} & \multirow{2}{*}{$\begin{array}{l}\text { Share of } \\
\text { Islamic } \\
\text { Banks } \\
\text { in Global } \\
\text { Islamic } \\
\text { Banking } \\
\text { Assets }(\%)\end{array}$} & \multirow{2}{*}{$\begin{array}{l}\text { Num. of } \\
\text { Islamic } \\
\text { Banks }\end{array}$} & \multirow{2}{*}{$\begin{array}{c}\text { Num. of } \\
\text { Conventional } \\
\text { Banks }\end{array}$} & \multicolumn{2}{|c|}{ Num. of Publicly Traded } \\
\hline & & & & & $\begin{array}{l}\text { Islamic } \\
\text { Banks }\end{array}$ & $\begin{array}{c}\text { Conventional } \\
\text { Banks }\end{array}$ \\
\hline Saudi Arabia & 51.30 & 31.59 & 5 & 10 & $5(100 \%)$ & $6(60.00 \%)$ \\
\hline $\begin{array}{l}\text { United Arabic } \\
\text { Emirates (U.A.E) }\end{array}$ & 17.40 & 12.52 & 4 & 6 & $4(100 \%)$ & $4(66.66 \%)$ \\
\hline Kuwait & 38.00 & 10.15 & 6 & 6 & $6(100 \%)$ & $6(100 \%)$ \\
\hline Qatar & 25.10 & 7.60 & 4 & 8 & $3(75.00 \%)$ & $5(62.50 \%)$ \\
\hline Bahrain & 12.70 & 2.84 & 9 & 12 & $4(44.44 \%)$ & $7(58.33 \%)$ \\
\hline Jordan & 11.70 & 0.83 & 3 & 13 & $2(66.66 \%)$ & $12(92.30 \%)$ \\
\hline Egypt & 6.70 & 1.99 & 3 & 15 & $3(100 \%)$ & $12(80.00 \%)$ \\
\hline Overall & - & 67.52 & 34 & 70 & $27(79.41 \%)$ & $52(74.28 \%)$ \\
\hline
\end{tabular}

This table shows the number of Islamic and conventional banks in each country and overall. The table also shows the market size of Islamic banks in each country and globally for 2014 (http://www.ifsb.org/docs/201505-20_IFSB\%20Islamic\%20Financial\%20Services\%20Industry\%20Stability\%20Report\%202015_final.pdf).

In measuring investor protection levels, I obtained protecting minority investors scores $(0-100)$ at the country-level from the World Bank Group. ${ }^{3}$ This score measures the extent of minority shareholder protection. The World Bank Group uses a set of indicators to measure overall minority investor protection scores for each country. These indicators include the extent of disclosure index (0-10); the extent of director liability index (0-10); the ease of shareholder suits index $(0-10)$; the strength of governance structure index $(0-10.5)$; the extent of shareholder rights index $(0$ 10.5); and the extent of corporate transparency index (0-9). I can only include pro-

\footnotetext{
${ }^{3} \mathrm{http} / / /$ www.doingbusiness.org/custom-query
} 
tecting minority investor scores $(\mathrm{CG})$ and the first three sub-classification index scores (i.e., the extent of disclosure index (0-10); the extent of director liability index $(0-10)$; and the ease of shareholder suits index (0-10)), as scores for other subclassifications are available from 2014. The selected sub-classifications measure three aspects of investor protection: the approval and transparency of related party transactions (i.e., the extent of disclosure index), the liability of company directors for self-dealing (i.e., extent of director liability index), and the shareholder's ability to obtain corporate documents before and during litigation (i.e., the ease of shareholder suits index).

Table 2 shows a descriptive analysis of average protecting minority investors and sub-classification index scores at the overall and country levels for 2003-2012. Table 2 also shows the World Bank rank of each country in the MENA region and globally. These rankings are based on two equally weighted indicators, namely "the extent of conflict of interest regulation index (0-10)," which is a simple average of the extent of director liability, the ease of shareholder suits and disclosure indices and "the extent of shareholder governance index (0-10)," which is a simple average of the extent of corporate transparency, shareholder rights and the strength of governance structure indices. 
Table 2: Protecting Minority Investors' Scores and Sub-Indices (2003-2012)

\begin{tabular}{|c|c|c|c|c|c|c|}
\hline $\begin{array}{l}\text { Sample } \\
\text { Countries }\end{array}$ & $\begin{array}{l}\text { Average } \\
\text { Protecting } \\
\text { Minority } \\
\text { Investors } \\
\text { Score } \\
(0-100)\end{array}$ & $\begin{array}{l}\text { Average } \\
\text { Extent } \\
\text { of } \\
\text { Disclosure } \\
\text { Index } \\
(0-10)\end{array}$ & $\begin{array}{l}\text { Average } \\
\text { Extent of } \\
\text { Director } \\
\text { Liability } \\
\text { Index } \\
(0-10)\end{array}$ & $\begin{array}{c}\text { Average } \\
\text { Ease of } \\
\text { Shareholder } \\
\text { Suits } \\
\text { Index } \\
(0-10)\end{array}$ & $\begin{array}{c}\text { MENA } \\
\text { Region } \\
\text { Ranking } \\
(\mathrm{N}=20)\end{array}$ & $\begin{array}{l}\text { Global } \\
\text { Ranking } \\
(\mathrm{N}=189)\end{array}$ \\
\hline Saudi Arabia & 62.38 & 7.57 & 7.57 & 3.57 & 4 & 62 \\
\hline U.A.E. & 40.00 & 4.00 & 6.00 & 2.00 & 1 & 43 \\
\hline Kuwait & 50.00 & 4.00 & 9.00 & 2.00 & 1 & 43 \\
\hline Qatar & 43.33 & 5.00 & 6.00 & 2.00 & 9 & 122 \\
\hline Bahrain & 46.67 & 8.00 & 4.00 & 2.00 & 7 & 104 \\
\hline Jordan & 30.00 & 4.00 & 4.00 & 1.00 & 16 & 154 \\
\hline Egypt & 35.23 & 4.57 & 3.00 & 3.00 & 13 & 135 \\
\hline Mean (AOA) & 43.94 & 5.30 & 5.65 & 2.22 & - & - \\
\hline Median (MOM) & 43.33 & 5.00 & 6.00 & 2.00 & - & - \\
\hline \multicolumn{7}{|l|}{$\begin{array}{l}\text { All Countries } \\
(\mathrm{N}=176)\end{array}$} \\
\hline Mean & 47.86 & 4.75 & 4.13 & 5.33 & & \\
\hline Median & 50 & 5.00 & 4.00 & 6.00 & & \\
\hline
\end{tabular}

The table shows average protecting minority investor scores and the three protecting minority investor score subclassification indices for the sampled countries and for all countries for 2003-2012. Protecting minority investor scores, sub-classification index scores, and rankings were obtained from the World Bank Group. It also shows country rankings based on protecting minority investor scores for the MENA region and globally for 2014. AOA refers to the average of the average, and MOM refers to the median of the median.

For 2003-2012, the 43.33 (43.94 average of average (AOA) protecting minority investors scores) median value of median (MOM) protecting minority investors scores for the sampled countries shows that minority investor protection levels are relatively lower relative to the global (i.e., 176 countries) median and average protecting minority investor scores, which are 50 and 47.86, respectively. For the subclassification index scores, the MOM of the ease of shareholder suits index (i.e., two) is substantially lower for my sample relative to the global median (i.e., six). At the country-level, Table 2 shows that Saudi Arabia and Jordan have the highest and the lowest average protecting minority investor scores of 62.38 and 30, respectively. 
Moreover, Saudi Arabia has the highest average ease of shareholder suits index score of 3.57, and Jordan has one of the lowest average extents of disclosure index scores of 4.00. Of the director liability index, Kuwait has the highest score of 9.00 and Egypt has the lowest score of 3.00. The global rankings (i.e., 189 countries) for 2014 show that the sample countries (especially Qatar, Egypt, and Jordan) present low levels of minority investor protection. In contrast, the sample countries (especially U.A.E, Kuwait, and Saudi Arabia) present high levels of minority investor protection. However, the MENA rankings (i.e., 20 countries) of 2014 show that the sample countries (especially U.A.E, Kuwait. Saudi Arabia and Bahrain) present higher levels of minority investor protection for the region.

\subsection{Regression Models}

In testing dividend stability levels, I use the partial adjustment dividend model (Lintner, 1956) and the earnings trend dividend model (Fama and Babiak, 1968). In the partial adjustment dividend model companies will only partially adjust their actual dividends to the target dividend level at the speed of the adjustment coefficient. Lintner (1956) show companies gradually adjust their dividends in regards to changes in earnings for any given year. Lintner (1956) show the partial adjustment dividend model as follow:

$D_{i,(t)}^{*}=r_{i} E_{i,(t)}$

Equation (1)

$D_{i,(t)}-D_{i,(t-1)}=\alpha_{i}+c_{i}\left(D_{i,(t)}^{*}-D_{i,(t-1)}\right)+v_{i,(t)}$ Equation (2)

In equation (1) " $\mathrm{D}_{\mathrm{i},(\mathrm{t})}^{*}$ " and " $\mathrm{r}_{\mathrm{i}}$ " represent the target level of dividends and desired payout ratio, respectively. The intercept of " $\alpha_{i}$ " in equation (2) implies the reluctance of managers to cut or decreasing the dividends. In addition, the coefficient of " $\mathrm{c}_{\mathrm{i}}$ " represents the speed of adjustment coefficient $\left(0<c_{i}<1\right)$. " $v_{i}$, (t)" is a serially independent error term. 
By substitution and replacing targeted dividend payments from equation (1) in equation (2), it can obtain the equation (3).

$D_{i,(t)}=\alpha_{i}+b_{i} E_{i,(t)}+d_{i} D_{i,(t-1)}+v_{i,(t)}$

Where, $b_{i}=c_{i} r_{i}$ and $d_{i}=\left(1-c_{i}\right)$

It is possible to modify model with implementing measurement of DPS (dividend per share) and EPS (earning per share) instead of dividend and earning, respectively. Therefore, the modified model to test stability of dividends obtains as follow:

$\operatorname{DPS}_{\mathrm{i},(\mathrm{t})}=\mathrm{a}_{1}+\mathrm{b}_{1} \mathrm{EPS}_{\mathrm{i},(\mathrm{t})}+\mathrm{b}_{2} \operatorname{DPS}_{\mathrm{i},(\mathrm{t}-1)}+\mathrm{v}_{\mathrm{i},(\mathrm{t})}$ Equation (4)

Fama and Babiak (1968) find that the addition of past earnings and past dividends results in a higher degree of explanatory power for the model. Hence, they reformulated the Lintner's partial adjustment model by incorporating a lagged earnings control variable. Fama and Babiak (1968) show the earnings trend dividend model as follow:

$\mathrm{E}_{\mathrm{i},(\mathrm{t})}=(1+\lambda) \mathrm{E}_{\mathrm{i},(\mathrm{t}-1)}+\mathrm{v}_{\mathrm{i},(\mathrm{t})}$

Equation (5)

Furthermore, they assume that there is a full adjustment of dividends to the expected earnings and only partial adjustments to the change between expected earnings and lagged dividends.

$D_{i,(t)}-D_{i,(t-1)}=a_{i}+c_{i}\left[r_{i}\left(E_{i,(t)}-\lambda_{i} E_{i,(t-1)}\right)-D_{i,(t-1)}\right]+r_{i} \lambda_{i}\left[E_{i,(t-1)}\right]+v_{i,(t)} \quad$ Equation (6)

$D_{i,(t)}=a_{i}+\left(1-c_{i}\right) D i,(t-1)+b_{i} E_{i,(t)}+d_{i} E_{i,(t-1)}+v_{i,(t)} \quad$ Equation (7)

Where, $b_{i}=c_{i} r_{i}$ and $d_{i}=r_{i} \lambda_{i}\left(1-c_{i}\right)$ 
Furthermore, in examining the relationship between protecting minority investor scores (CG) and dividend payout ratios, I use the following models:

$$
\begin{aligned}
\text { Payout }_{\mathrm{i},(\mathrm{t})} & =\alpha_{0}+\alpha_{1} \mathrm{CG}_{\mathrm{i},(\mathrm{t})}+\alpha_{2} \text { Growth }_{\mathrm{i},(\mathrm{t})}+\alpha_{3} \mathrm{CG}_{\mathrm{i},(\mathrm{t})} * \text { Growth }_{\mathrm{i},(\mathrm{t})} \\
& +\beta_{\mathrm{i}} \text { Control }_{\mathrm{i},(\mathrm{t})}+\text { Year dummies }_{(\mathrm{t})}+\varepsilon_{\mathrm{i},(\mathrm{t})}
\end{aligned}
$$

As in the LLSV model, dividends to earnings and dividends to cash flow are used as dependent variables (Payout). I use the protecting minority investor scores (CG) and include Tobin's $q$ (Growth) as a proxy for growth opportunity. I also include the interaction effect (CG*Growth) between $\mathrm{CG}$ and Growth. I use the control variables (Control) (profitability, leverage, asset compositions and size), whose expected signs and descriptions are shown in Table 3 for both Islamic and conventional banks. Except for Saudi Arabia wherein dividend taxes are very low and only apply to nonresidents, dividends are not taxable for residents and non-residents in other sample countries. ${ }^{4}$ Therefore, I exclude dividend tax as a control variable in my models.

I also use the following model to study the relationship between CG's subclassifications index scores and dividend payout ratios:

$$
\begin{aligned}
\text { Payout }_{\mathrm{i},(\mathrm{t})} & =\alpha_{0}+\alpha_{1} \text { Subclass }_{\mathrm{i} 1,(\mathrm{t})}+\alpha_{2} \text { Subclass }_{\mathrm{i} 2,(\mathrm{t})}+\alpha_{3} \text { Subclass }_{\mathrm{i} 3,(\mathrm{t})} \\
& +\beta_{\mathrm{i}} \text { Control }_{\mathrm{i},(\mathrm{t})}+\text { Year dummies }_{(\mathrm{t})}+\varepsilon_{\mathrm{i},(\mathrm{t})}
\end{aligned}
$$

Sub-classification indices (Subclass) include the ease of shareholder suit index (Subclass $\left._{\mathrm{i} 1}\right)$; the extent of director liability index (Subclass $\left.\mathrm{s}_{\mathrm{i}}\right)$, and the extent of disclosure index (Subclass $\mathrm{i}_{\mathrm{i}}$ ). I use Tobin's $q$ (Growth) and the same control variables (Control) shown in the model (1).

\footnotetext{
${ }^{4}$ http://www.ey.com/GL/en/Services/Tax/Global-tax-guide-archive.
} 


\subsection{Method of Estimation}

I use panel data analysis and winsorize the data for each year at the top and bottom $1 \%$ to avoid adverse outlier's effect on estimations. In testing dividend stability levels through partial adjustment and earnings trend dividend models, I use pooled ordinary least squares (OLS), fixed effects and dynamic general methods of moments system (GMM in-Sys) econometric methods. For the panel data series set, the OLS estimators can be inconsistent and biased due to the potential correlation of regressors and lagged dependent variable across firms with the firm-specific effect, and potential endogeneity problems. In order to find out consistent and unbiased estimation results, I focus on the dynamic estimation results by general method of moments (GMM), as OLS estimators can be inconsistent and biased as a result of potential endogeneity problems. Arellano and Bond (1991) suggest an instrumental variable approach [GMM (in-Diff)] by using lagged twice and earlier instrument for dependent variable in the first-differenced equation.

Furthermore, it is likely that shocks affecting dividend choices may also affect other measured financial variables (i.e., endogeneity of regressors); they develop a GMM technique by using lagged dated ( $\mathrm{t}-2)$ for such predetermined variables in-firstdifferences. However, a further refinement is developed by Arellano and Bover (1995) and Blundell and Bond (1998) and they show that the [GMM (in-Diff)] instrumental variables are not efficient in dynamic panel data models where the autoregressive parameter is moderately large and the number of time series observations is moderately small. Therefore, they propose the [GMM (in-Sys)], which this method uses lagged differences of the series as instruments for the equation in levels in addition to lagged levels of the series as instruments for the equation in first differences. 
In determining the consistency of estimators by [GMM (in-Sys)], I test the validity of instruments using the Hansen test, and I test serial correlations using the $\mathrm{M}_{2}$ test.

In estimating models, I use both the random effects model and random-effects Tobit method by including year dummies. A Tobit model can be applicable where a dependent variable is censored within a certain range. In the case of dividend modeling, dependent variables are censored at zero for banks that do not pay dividends. Tobit estimations allow us to eliminate biases related to OLS regressions (Greene, 2012; Kim and Maddala, 1992). I use the $\log$ likelihood ratio test ${ }^{5}$ to check the validity of random-effects Tobit model to the pool Tobit model.

\subsection{Explanatory Variables}

Table 3 presents a description of all variables included in the equations and models and their expected signs for Islamic and conventional banks. As discussed above, I use protecting minority investor protection scores $(\mathrm{CG})$ of the World Bank Group at the country-level and their first three sub-classification indices: the extent of disclosure index (0-10); the extent of director liability index (0-10) and the ease of shareholder suits index (0-10). The extent of disclosure index measures review and approval requirements for related party transactions. The extent of director liability index also measures minority shareholder capacities to sue and hold interested directors liable for prejudicial party transactions. Finally, the ease of shareholder suits index measures shareholders capacities to obtain corporate documents before and during litigation. In testing the effect of each sub-classification index on dividend payouts, I use a dummy variable that is equal to one when the sub-classification index score exceeds the sample median.

\footnotetext{
${ }^{5}$ A likelihood-ratio test shows that if the null hypothesis $(\mathrm{rho}=0)$ is rejected, random effects Tobit model is more appropriate rather than the pooled Tobit model.
} 
For Islamic banks, in line with the substitute agency model of dividends, the expected signs of CG and sub-classification index scores are negative. I expect a positive relationship between Growth and dividend payouts. As I do not know which agency model (i.e., the substitute or the outcome model) can explain the dividend policy behaviors of conventional banks, expected CG score signs, sub-classification index scores and Growth are ambiguous. If it is the outcome agency model, the expected signs for CG and sub-classification index scores are positive whereas the expected sign for Growth is negative.

In line with prior empirical research, I use similar control variables. Profitability has a positive association with dividend payouts (Akpomi and Nnadi, 2008; Al-Malkawi, 2007; Ben Naceur et al., 2006; Bodla et al., 2007; Fama and French, 2001; Gupta and Walker, 1975; Han et al., 1999; Jensen et al., 1992; Lee, 2009). I use the one-year change in earnings as a proxy for profitability rather than using returns on assets or equity in order to avoid endogeneity problems between profitability and corporate governance. Mitton (2004) finds that the quality of corporate governance has a positive effect on profitability. He shows that both indirect and direct effects of profitability and governance quality have explanatory power for payouts. I expect a positive association between profitability and dividend payouts for both types of banks.

I also control for asset compositions. For Islamic banks, the asset compositions ratio is calculated by dividing the number of investment accounts (i.e., total profit-loss sharing investment and mark-up financing accounts) by total assets. For conventional banks, the equivalent ratio is the total loans divided by total assets (Greuning and Iqbal, 2008, p. 93-94). As the asset compositions of Islamic banks present unstable rates of return as a result of profit and loss investment (i.e., Musharaka and 
Mudaraba) and more significant agency problems than conventional banks (Aggarwal and Yousef, 2000; Bacha, 1995; Hassan et al., 2003), I expect the asset compositions control variable to have a negative effect on Islamic bank dividend payouts. For the conventional banks, the expected sign depends on the quality of the loan portfolio. For instance, asset compositions can have a negative effect on dividend payouts when the ratio of non-performing loans to total loans is high.

Size is another significant determinant of dividend policies (Dickens et al., 2002; Imran et al., 2013; Kennedy and Scott, 1984; Lee, 2009). Large companies enjoy greater access to capital markets and are more likely to pay higher dividends than small companies (Al-Malkawi, 2007; Holder et al., 1998; Lloyd et al., 1985). Furthermore, managers of large companies are presented with more incentives to payout dividends in order to mitigate agency problems. In large companies, shareholder expropriation is more likely due to the presence of higher free cash flows and revenues. I use a natural logarithm of total assets as a proxy for the size control variable, and I expect to find a positive relationship between size and dividend payouts for both Islamic and conventional banks.

Profit sharing investment accounts are not a liability (Accounting and Auditing Organization for Islamic Financial Institutions (AAOIFI), 1993) and investment account holders have only a residual claim to earnings in Islamic banks. Moreover, the commingling of depositor and shareholder funds and profits through the Mudarib mechanism (Mudarib fee) present significant implications for the capital structures of Islamic banks. Archer et al. (1998) state that, "Given that shareholders can in principle increase their rate of return at no extra risk to their equity by increasing their return from the Mudarib share, it would seemingly be in their best interests to maintain 
their equity at a minimum and increase investment account financing to the highest level possible" (p. 161). Karim and Ali (1989) and Karim (1996) show that this capital structure composition is common in Islamic banks. Empirical evidence presented by Al-Deehani et al. (1999) supports this claim by showing that in increasing investment account financing yields, shareholder rates of return increase with no extra financial risk. In other words, through high ratios of investment deposits to shareholder funds (i.e., higher leverage), shareholders of Islamic banks can benefit from increasing returns from the Mudarib share at the expense of Islamic depositors.

However, managers of highly leveraged conventional banks are likely to exploit insured depositors by increasing payouts, especially in competitive and effective regulation environments as shown in Figure 2 (Nienhaus, 2007). Conventional banks are more likely to retain their earnings in order to avoid volatility risks and to reduce transaction costs of external borrowing (Gugler and Yurtoglu, 2003; Jensen et al., 1992; Rozeff, 1982). In light of these arguments, I use the ratio of total liabilities to total equities as a proxy for the leverage control variable, and I expect to find a positive and negative relationship between leverage and dividend payouts for Islamic and conventional banks. 
Table 3: Variable Descriptions and Expected Signs

\begin{tabular}{|c|c|c|c|}
\hline Variables & \multicolumn{2}{|c|}{ Signs } & Descriptions \\
\hline Dependent Variables & & & \\
\hline Dividend payout ratio & & & Dividends per share to the earnings per share ratio \\
\hline Dividend-to-cash flow ratio & & & Dividends per share to the cash flow per share ratio \\
\hline Explanatory Variables & IS & $\mathrm{CV}$ & \\
\hline $\begin{array}{l}\text { Protecting minority } \\
\text { investor score }\end{array}$ & - & $+/-$ & $\begin{array}{l}\text { The protecting minority investor score is measured by considering } \\
\text { indicators of the extent of disclosure index }(0-10) \text {, the extent of } \\
\text { director liability index }(0-10) \text {, the ease of shareholder suits index } \\
(0-10) \text {, the extent of shareholder rights index }(0-10.5) \text {, the strength } \\
\text { of governance structure index }(0-10.5) \text {, and the extent of corpo- } \\
\text { rate transparency index }(0-9) \text {. The maximum protecting minority } \\
\text { investor score that a country can obtain is } 100 \text {. Therefore, coun- } \\
\text { tries with higher levels of minority investor protection should } \\
\text { achieve higher scores. }\end{array}$ \\
\hline $\begin{array}{l}\text { Ease of shareholder suits } \\
\text { index }\end{array}$ & - & $+1-$ & $\begin{array}{l}\text { Measures shareholder capacities to obtain corporate documents } \\
\text { before and during litigation. The index ranges from } 0 \text { to } 10 \text {. High- } \\
\text { er values indicate stronger powers for shareholders in challenging } \\
\text { transactions. }\end{array}$ \\
\hline $\begin{array}{l}\text { Extent of director liability } \\
\text { index }\end{array}$ & - & $+/-$ & $\begin{array}{l}\text { Measures minority shareholder capacities to sue and hold interest- } \\
\text { ed directors liable for prejudicial party transactions. The index } \\
\text { ranges from } 0 \text { to } 10 \text {. Higher values indicate higher levels of direc- } \\
\text { tor liability. }\end{array}$ \\
\hline $\begin{array}{l}\text { Extent of disclosure } \\
\text { index }\end{array}$ & - & $+1-$ & $\begin{array}{l}\text { Measures review and approval requirements for related party } \\
\text { transactions. The index ranges from } 0 \text { to } 10 \text {. Higher values denote } \\
\text { higher levels of disclosure. }\end{array}$ \\
\hline Growth & + & $+1-$ & $\begin{array}{l}\text { Market value of equity and liability to the book value of the equi- } \\
\text { ty and liabilities ratio. }\end{array}$ \\
\hline Profitability & + & + & Percentage change in net income over the next year \\
\hline Leverage & + & - & Total liability to total equity ratio \\
\hline Asset compositions & - & $-1+$ & $\begin{array}{l}\text { Total profit loss sharing (PLS) and mark-up-based financing to } \\
\text { the total assets ratio for Islamic banks and total loans to the total } \\
\text { asset ratio for conventional banks. }\end{array}$ \\
\hline Size & + & + & Natural logarithm of total assets \\
\hline
\end{tabular}

IS refers to Islamic banks and CV refers to conventional banks. 


\section{Chapter 5}

\section{EMPIRICAL RESULTS}

\subsection{Descriptive Analysis}

\subsubsection{Dividend Payouts}

Table 4 shows the descriptive statistics on the dividend payout ratio at the countryand aggregate levels. I also examine effects of the contagious 2008 U.S. subprime mortgage crisis by investigating the ratios for two periods: the pre-crisis period (2003-2007) and the post-crisis period (2008-2012). An overall comparative analysis between conventional and Islamic publicly traded banks shows that conventional banks with a $39.90 \%$ median dividend payout ratio have higher dividend payout ratios than Islamic banks with a $24.90 \%$ median dividend payout ratio. Both the overall mean and median dividend payout ratios for Islamic and conventional banks are significantly different ${ }^{6}$. The overall standard deviation (26\%) of the dividend payout ratio for Islamic banks is higher than the overall standard deviation (13\%) for conventional banks. Islamic banks present more volatile dividend payout ratios.

The univariate results on the mean and median overall dividend payout ratio does not support the expectation that Islamic banks with relatively higher agency costs should pay out more than conventional banks. However, this finding may be related to profitability differences between the two types of banks. Consequently, a more in-depth

\footnotetext{
${ }^{6}$ I exclude the results for the mean dividend payout ratios from the Table 4 due to the similarities of results between mean and median dividend payout ratios for both types of banks.
} 
regression analysis is needed to test differences between the two. Moreover, the country-level results are mixed. Difference tests on mean (Mean t-test) and median (Mann-Whitney $U$-test) values of the overall dividend payout ratios for each country show that with the exception of Bahrain, Kuwait, and Egypt, mean and median values between Islamic and conventional banks are not statistically different. Moreover, Egypt, Bahrain, and Kuwait present the lowest dividend mean and median dividend payout ratios of the Islamic banks.

In Table 4, for the pre-crisis (2003-2007) and post-crisis (2008-2012) periods, I also show mean and median dividend payout ratios at the aggregate (overall) and country levels. The median difference test results (Mann-Whitney $U$-test) show that overall median dividend payout ratios are not significantly different between the two periods for both conventional and Islamic banks. At the overall level, I do not find statistically significant effects of the crisis. However, at the country level, in Bahrain and $\mathrm{Ku}-$ wait, the median dividend payout ratio of conventional banks decreases at a statistically significant level. However, in Qatar, Egypt and Jordan, there is a statistically significant increase in the median dividend payout ratio for conventional banks. No statistically significant change is found for conventional banks in Saudi Arabia or the U.A.E. For the Islamic banks, the findings are interesting at the country-level, and no univariate empirical evidence for any adverse crisis effects on the dividend payout ratios of Islamic banks are found for any of the countries examined. No statistically significant change in the dividend payout ratios of Islamic banks is found between the two periods. Beck et al. (2013) show that Islamic banks presented higher levels of asset quality and were better capitalized than conventional banks during the financial crisis. 
Table 4: Descriptive Analysis: Dividend Payout Ratios (Overall and Pre- vs. Post-Subprime Mortgage Crisis Periods)

\begin{tabular}{|c|c|c|c|c|c|c|c|c|c|c|c|c|c|c|c|}
\hline \multirow[b]{4}{*}{ Country } & \multirow{2}{*}{\multicolumn{7}{|c|}{ Conventional Banks (CV) }} & & & & & & & & \\
\hline & & & & & & & & \multicolumn{7}{|c|}{ Islamic Banks (IS) } & \\
\hline & \multicolumn{2}{|c|}{$\begin{array}{l}2003-2007 \\
\text { (Pre-crisis) }\end{array}$} & \multicolumn{2}{|c|}{$\begin{array}{c}\text { 2008-2012 } \\
\text { (Post-crisis) }\end{array}$} & \multirow{2}{*}{$\begin{array}{c}\text { Diff. } \\
U \text {-test } \\
(\mathrm{CV})\end{array}$} & \multicolumn{2}{|c|}{$\begin{array}{c}2003-2012 \\
\text { (Overall) }\end{array}$} & \multicolumn{2}{|c|}{$\begin{array}{l}\text { 2003-2007 } \\
\text { (Pre-crisis) }\end{array}$} & \multicolumn{2}{|c|}{$\begin{array}{c}2008-2012 \\
\text { (Post-crisis) }\end{array}$} & \multirow{2}{*}{$\begin{array}{c}\text { Diff. } \\
U \text {-test } \\
\text { (IS) }\end{array}$} & \multicolumn{2}{|c|}{$\begin{array}{c}2003-2012 \\
\text { (Overall) }\end{array}$} & \\
\hline & Median & $\begin{array}{c}\text { St. } \\
\text { Dev. }\end{array}$ & Median & $\begin{array}{c}\text { St. } \\
\text { Dev. }\end{array}$ & & Median & $\begin{array}{c}\text { St. } \\
\text { Dev. }\end{array}$ & Median & $\begin{array}{c}\text { St. } \\
\text { Dev. }\end{array}$ & Median & $\begin{array}{c}\text { St. } \\
\text { Dev. }\end{array}$ & & Median & $\begin{array}{c}\text { St. } \\
\text { Dev. }\end{array}$ & $\begin{array}{c}U \text {-test } \\
\text { Overall }\end{array}$ \\
\hline Saudi Arabia & 31.6 & 14.5 & 31.6 & 3.2 & $\begin{array}{c}41.8 \\
(0.67)\end{array}$ & 31.6 & 10.9 & 21.3 & 9.1 & 18.7 & 11.2 & $\begin{array}{c}0.62 \\
(0.53)\end{array}$ & 23.1 & 23.1 & $\begin{array}{c}1.47 \\
(0.14)\end{array}$ \\
\hline Bahrain & 46.7 & 5.7 & 34.1 & 6.5 & $\begin{array}{c}2.089 * * \\
(0.03)\end{array}$ & 42.8 & 8.7 & 22.8 & 8.2 & 16.7 & 11.4 & $\begin{array}{c}1.04 \\
(0.29)\end{array}$ & 19.2 & 13.6 & $\begin{array}{l}3.28 * \\
(0.00)\end{array}$ \\
\hline Qatar & 46.8 & 13.7 & 63.2 & 3.9 & $\begin{array}{c}1.88 * * * \\
(0.06)\end{array}$ & 59.5 & 13.2 & 26 & 11.1 & 65 & 9.3 & $\begin{array}{c}0.62 \\
(0.53)\end{array}$ & 63 & 31.5 & $\begin{array}{c}0.64 \\
(0.52)\end{array}$ \\
\hline Kuwait & 51.7 & 6.1 & 25.3 & 5 & $\begin{array}{l}2.50 * * \\
(0.01)\end{array}$ & 41.5 & 15.1 & 33.1 & 7.2 & 18.8 & 4.9 & $\begin{array}{c}0.41 \\
(0.67)\end{array}$ & 21.8 & 13.3 & $\begin{array}{l}2.53 * * \\
(0.01)\end{array}$ \\
\hline U.A.E. & 37.1 & 13.2 & 39.9 & 14.3 & $\begin{array}{c}0.20 \\
(0.83)\end{array}$ & 38.5 & 13 & 16.4 & 11.9 & 23 & 12.4 & $\begin{array}{c}0.62 \\
(0.53)\end{array}$ & 27.6 & 26.4 & $\begin{array}{c}0.79 \\
(0.42)\end{array}$ \\
\hline Egypt & 31.3 & 10 & 40.9 & 5.1 & $\begin{array}{c}1.88^{* * * *} \\
(0.06)\end{array}$ & 39.7 & 9.9 & 16.3 & 16.9 & 1.2 & 10.9 & $\begin{array}{c}1.49 \\
(0.13) \\
\end{array}$ & 10 & 15.8 & $\begin{array}{l}2.70^{*} \\
(0.00) \\
\end{array}$ \\
\hline Jordan & 21.6 & 11.8 & 40.3 & 6.1 & $\begin{array}{c}1.88 * * * \\
(0.06)\end{array}$ & 35.2 & 13 & 30.7 & 14.7 & 25.7 & 17.1 & $\begin{array}{c}0.83 \\
(0.40)\end{array}$ & 39.5 & 21.6 & $\begin{array}{c}0.94 \\
(0.34)\end{array}$ \\
\hline Overall & 41 & 14.3 & 37.3 & 12.9 & $\begin{array}{c}0.36 \\
(0.71)\end{array}$ & 39.9 & 13 & 30.7 & 29.6 & 21.5 & 21.3 & $\begin{array}{c}1.54 \\
(0.13)\end{array}$ & 24.9 & 26 & $\begin{array}{l}3.91^{*} \\
(0.00)\end{array}$ \\
\hline
\end{tabular}

The table shows effects of the contagious subprime mortgage crisis (pre- and post-crisis) on the actual dividend payout ratios. In addition, for the entire sample period (2003-2012), it compares the actual dividend payout ratios of Islamic and conventional banks. Mean, median and standard deviation values are reported as percentages. Numbers shown in parentheses are $\mathrm{p}$ values. *significance at $1 \%, * *$ significance at $5 \%$, ***significance at $10 \%$. 


\subsubsection{Dividend Behaviors to the Earning Changes / Signs}

Table 5 represents the dividend policy reactions to the changes of earnings and signs of earnings. In order to carry out the dividend reaction analysis to the changes of earnings, I categorize the changes of earnings to the three different states. If earnings per share increases or decreases, it captures as “+” or “-”. However, if earnings per share are not to change, it assumes as "No change". Likewise, I classify the dividend reactions to the percentage increased or decreased of dividends, percentage constant of dividends, percentage omitted and continues of omission of dividends.

Panel (A, B) shows the percentage of increased dividends to the positive or negative changes of earning are substantially higher at conventional banks by $58.82 \%$ and $27.74 \%$ relative to Islamic banks by $40.87 \%$ and $14.47 \%$, respectively. In addition, it shows the percentage omitted and continues of omission of dividends to the positive or negative changes of earning are substantially lower in conventional banks relative to counterparts. In "No Change" state, the percentage of increased or decreased dividends in Islamic banks is significantly higher by $66.66 \%$ and $33.34 \%$ relative to conventional banks by $11.11 \%$ and $22.22 \%$, respectively. Panel (A, B) also shows the dividend reactions to the sign of earnings. In this order, I classify the dividend reactions to the percentage of dividend payers and non-payers. In the case of negative sign of earnings, Islamic banks pay dividend by $17.85 \%$ whereas conventional banks do not payout dividend. However, In the case of positive sign of earnings conventional banks pay dividend by $79.16 \%$ that is relatively higher than Islamic banks by $62.18 \%$ 
Table 5: Dividend Behaviors to the Earning Changes / Signs (2003-2012)

\begin{tabular}{|c|c|c|c|c|c|c|}
\hline \multicolumn{7}{|c|}{ Panel A: Islamic Banks } \\
\hline $\begin{array}{l}\text { Earning } \\
\text { Changes }\end{array}$ & Percentage & $\begin{array}{l}\text { \%Increased } \\
\text { Dividends }\end{array}$ & $\begin{array}{l}\text { \% Decreased } \\
\text { Dividends }\end{array}$ & $\begin{array}{l}\text { \%Constant } \\
\text { Dividends }\end{array}$ & $\begin{array}{l}\% \text { Omitted } \\
\text { Dividends }\end{array}$ & $\begin{array}{l}\text { \%Continued } \\
\text { Dividends }\end{array}$ \\
\hline+ & $59.27 \%$ & $40.87 \%$ & $12.17 \%$ & $6.95 \%$ & $4.36 \%$ & $35.65 \%$ \\
\hline- & $39.17 \%$ & $14.47 \%$ & $34.21 \%$ & $3.95 \%$ & $14.47 \%$ & $32.90 \%$ \\
\hline No Change & $1.56 \%$ & $66.66 \%$ & $33.34 \%$ & & & \\
\hline No. Of Obs. & 194 & & & & & \\
\hline & Percentage & \multicolumn{2}{|c|}{ \%Dividend Payers } & \multicolumn{2}{|c|}{ \%Dividend Non-Payers } & \\
\hline EPS $>0$ & $87.33 \%$ & \multicolumn{2}{|c|}{$62.18 \%$} & \multicolumn{2}{|c|}{$37.82 \%$} & \\
\hline EPS $<0$ & $12.67 \%$ & \multicolumn{2}{|c|}{$17.85 \%$} & \multicolumn{2}{|c|}{$82.15 \%$} & \\
\hline No. Of Obs. & 221 & & & & & \\
\hline \multicolumn{7}{|c|}{ Panel B: Conventional Banks } \\
\hline $\begin{array}{l}\text { Earning } \\
\text { Changes }\end{array}$ & Percentage & $\begin{array}{l}\text { \%Increased } \\
\text { Dividends }\end{array}$ & $\begin{array}{l}\text { \%Decreased } \\
\text { Dividends }\end{array}$ & $\begin{array}{l}\text { \%Constant } \\
\text { Dividends }\end{array}$ & $\begin{array}{l}\% \text { Omitted } \\
\text { Dividends }\end{array}$ & $\begin{array}{l}\text { \%Continued } \\
\text { Dividends }\end{array}$ \\
\hline+ & $60.86 \%$ & $58.82 \%$ & $11.76 \%$ & $13.33 \%$ & $3.15 \%$ & $12.94 \%$ \\
\hline- & $37.00 \%$ & $27.74 \%$ & $24.51 \%$ & $14.83 \%$ & $13.57 \%$ & $19.35 \%$ \\
\hline No Change & $2.14 \%$ & $11.11 \%$ & $22.22 \%$ & $11.11 \%$ & $0.00 \%$ & $55.56 \%$ \\
\hline \multirow[t]{2}{*}{ No. Of Obs. } & 419 & & & & & \\
\hline & Percentage & \multicolumn{2}{|c|}{$\%$ Dividend Payers } & \multicolumn{2}{|c|}{$\%$ Dividend Non-Payers } & \\
\hline EPS $>0$ & $97.22 \%$ & \multicolumn{2}{|c|}{$79.16 \%$} & \multicolumn{2}{|c|}{$20.84 \%$} & \\
\hline EPS $<0$ & $2.78 \%$ & \multicolumn{2}{|c|}{$0.00 \%$} & \multicolumn{2}{|c|}{$100 \%$} & \\
\hline No. Of Obs. & 469 & & & & & \\
\hline
\end{tabular}

\subsection{Dividend Stability}

Table 5 shows the estimation results of static (i.e., pooled OLS and fixed effects) and dynamic (i.e., GMM-System) panel data regressions for the traditional dividend models, namely the partial adjustment dividend model (A) and the earnings trend dividend model (B). In all estimation results of model A, the lagged dividend per share and earnings per share are statistically significant and positively affect the dividend payout ratios of both conventional and Islamic banks. However, according to the estimation results of model B, I do not find strong empirical evidence for current and lagged earnings per share effects on dividend payouts. Therefore, I focus on the 
estimation results of model A. In the following discussion, I consider the dynamic GMM-System results that are consistent with actual payout ratios shown in Table 4. The $\mathrm{p}$-value for Hansen test and $\mathrm{M}_{2}$ test shows the validity of GMM-System results.

Islamic and conventional banks have the speed of adjustment coefficients of $46.70 \%$ and $32.10 \%$, respectively. The results for the speed of adjustment coefficients show that both types of banks employ stable dividend policies, but conventional banks have more stable dividend payments. However, Islamic banks adjust their dividend payouts to the targeted dividend payout ratio at a faster rate. Furthermore, the estimated coefficients for lagged dividend per share are 0.533 and 0.679 for Islamic banks and conventional banks, respectively. The higher coefficient for conventional banks indicates that dividend payments are more sensitive to lagged dividend payments. The target dividend payout ratios of Islamic and conventional banks are similar, and their respective values are $50.10 \%$ and $53.20 \%$, respectively. For Islamic banks, there is a more significant difference between target and actual dividend payouts (i.e., see Table 4 for actual dividend payouts). However, Islamic bank managers adjust their dividend payments at a relatively faster rate in order to reach target payout ratios sooner.

In summary, contrary to the agency theory that predicts higher dividend payouts and stable dividend policies for Islamic banks, dividend stability empirical results show that Islamic banks have lower target dividend payouts and less stable dividend payments. In contrast, conventional banks have higher target dividend payouts and more stable dividend payments. The findings are in line with (Aivazian et al., 2003; Lin, 2002), and support that corporate governance and accessibility to capital markets can affect significantly on dividend stability. The dividend stability results show that 
conventional banks due to relatively better quality of corporate governance and greater accessibility for external financing have more stable dividend payments and their dividend policies are less responsive to changes in earnings.

These findings also support the LLSV (2000) and show that investor protection is a significant determinant of dividend policies. In another word, Islamic banks due to the relatively lower investor protection are less likely to payout higher dividends and follow conventional banks dividend policies. Islamic banks are more likely to follow the substitute agency model whereas conventional banks are more likely follow the outcome agency model of dividends. However, according to LLSV (2000), I need to consider the effects of growth opportunities and strength of investor protection in order to find out which of the two agency dividend models are certainly valid. Therefore, I carry out further multivariate regression analysis in the following sections. 
Table 6: Traditional Dividend Model Analysis: Islamic vs. Conventional Banks (2003-2012)

\begin{tabular}{|c|c|c|c|c|c|c|c|c|c|c|c|c|}
\hline & \multicolumn{6}{|c|}{ Islamic Banks } & \multicolumn{6}{|c|}{ Conventional Banks } \\
\hline & \multicolumn{2}{|c|}{ Pooled OLS } & \multicolumn{2}{|c|}{ Fixed Effects } & \multicolumn{2}{|c|}{ GMM-System } & \multicolumn{2}{|c|}{ Pooled OLS } & \multicolumn{2}{|c|}{ Fixed Effects } & \multicolumn{2}{|c|}{ GMM-System } \\
\hline & Divide & Models & Divide & Models & Dividen & Models & Divide & Models & Dividen & Models & Divide & Models \\
\hline Variables & $\mathrm{A}$ & $\mathrm{B}$ & A & $\mathrm{B}$ & $\mathrm{A}$ & $\mathrm{B}$ & $\mathrm{A}$ & $\mathrm{B}$ & $\mathrm{A}$ & $\mathrm{B}$ & $\mathrm{A}$ & $\mathrm{B}$ \\
\hline $\begin{array}{l}\text { Lagged dividend } \\
\text { per share }\end{array}$ & $\begin{array}{c}0.598^{*} \\
(3.59) \\
\end{array}$ & $\begin{array}{l}0.543^{*} \\
(2.77) \\
\end{array}$ & $\begin{array}{l}0.479 * \\
(6.61)\end{array}$ & $\begin{array}{c}0.461 * \\
(5.80) \\
\end{array}$ & $\begin{array}{l}0.533^{*} \\
(3.39) \\
\end{array}$ & $\begin{array}{l}0.518^{*} \\
(3.15)\end{array}$ & $\begin{array}{l}0.678^{*} \\
(4.89) \\
\end{array}$ & $\begin{array}{l}0.680^{*} \\
(12.01) \\
\end{array}$ & $\begin{array}{l}0.478^{*} \\
(14.54) \\
\end{array}$ & $\begin{array}{l}0.522 * \\
(7.20) \\
\end{array}$ & $\begin{array}{l}0.679^{*} \\
(3.93)\end{array}$ & $\begin{array}{l}0.653^{*} \\
(18.66) \\
\end{array}$ \\
\hline $\begin{array}{l}\text { Current earnings } \\
\text { per share }\end{array}$ & $\begin{array}{c}0.197 * * * \\
(1.78)\end{array}$ & $\begin{array}{l}0.134 \\
(1.56)\end{array}$ & $\begin{array}{c}0.124 * * \\
(2.33)\end{array}$ & $\begin{array}{c}0.109 * * * \\
(1.82)\end{array}$ & $\begin{array}{c}0.234^{* *} \\
(2.15) \\
\end{array}$ & $\begin{array}{l}0.129 \\
(1.54)\end{array}$ & $\begin{array}{l}0.175^{*} \\
(5.61)\end{array}$ & $\begin{array}{l}0.175^{*} \\
(10.07)\end{array}$ & $\begin{array}{l}0.279^{*} \\
(19.85)\end{array}$ & $\begin{array}{l}0.289^{*} \\
(14.33)\end{array}$ & $\begin{array}{l}0.171^{*} \\
(7.46)\end{array}$ & $\begin{array}{l}0.171^{*} \\
(10.25)\end{array}$ \\
\hline $\begin{array}{l}\text { Lagged earnings } \\
\text { per share }\end{array}$ & & $\begin{array}{l}0.104 \\
(1.23)\end{array}$ & & $\begin{array}{l}0.062 \\
(0.57)\end{array}$ & & $\begin{array}{l}0.105 \\
(0.98)\end{array}$ & & $\begin{array}{l}-0.001 \\
(-0.01)\end{array}$ & & $\begin{array}{l}-0.017 \\
(-0.68)\end{array}$ & & $\begin{array}{l}0.008 \\
(0.10)\end{array}$ \\
\hline Constant & $\begin{array}{c}0.297 * * * \\
(1.73)\end{array}$ & $\begin{array}{c}0.314 * * * \\
(1.76)\end{array}$ & $\begin{array}{l}-0.068 \\
(-0.44) \\
\end{array}$ & $\begin{array}{l}-0.126 \\
(-0.68) \\
\end{array}$ & $\begin{array}{l}0.282 \\
(1.33)\end{array}$ & $\begin{array}{l}0.003 \\
(0.05) \\
\end{array}$ & $\begin{array}{l}0.038 \\
(0.19) \\
\end{array}$ & $\begin{array}{l}0.036 \\
(0.32) \\
\end{array}$ & $\begin{array}{l}0.006 \\
(0.06) \\
\end{array}$ & $\begin{array}{l}-0.225 \\
(-0.82) \\
\end{array}$ & $\begin{array}{l}0.062 \\
(0.30)\end{array}$ & $\begin{array}{c}0.174 * * * \\
(1.90)\end{array}$ \\
\hline Year dummies & YES & YES & YES & YES & YES & YES & YES & YES & YES & YES & YES & YES \\
\hline Hausman-test & & & $(0.00)$ & $(0.00)$ & & & & & $(0.00)$ & $(0.00)$ & & \\
\hline Hansen-test & & & & & $(0.624)$ & $(0.650)$ & & & & & $(0.501)$ & $(0.324)$ \\
\hline $\mathrm{M}_{2}$-test & & & & & $(0.418)$ & $(0.329)$ & & & & & $(0.389)$ & $(0.405)$ \\
\hline No. Of obs. & 174 & 173 & 98 & 98 & 174 & 173 & 401 & 400 & 252 & 251 & 401 & 400 \\
\hline R-squared & $73 \%$ & $73 \%$ & $54 \%$ & $54 \%$ & & & $84 \%$ & $84 \%$ & $71 \%$ & $71 \%$ & & \\
\hline Speed of adjustment & $40.2 \%$ & & $52.1 \%$ & & $46.7 \%$ & & $32.2 \%$ & & $52.2 \%$ & & $32.1 \%$ & \\
\hline Target payout ratio & $49 \%$ & & $23.8 \%$ & & $50.1 \%$ & & $54.3 \%$ & & $53.4 \%$ & & $53.2 \%$ & \\
\hline
\end{tabular}

The table reports regression coefficients of the partial adjustment dividend model (A) and earnings trend dividend model (B). The Hansen statistic is a test of over-identifying restrictions, asymptotically distributed as $\mathrm{x}^{2}(\mathrm{k})$ under the null of valid instruments. $\mathrm{M}_{2}$ tests the absence of second-order serial correlations in residuals, asymptotically distributed as $\mathrm{N}(0,1)$ under the null of no serial correlation. Standard errors are asymptotically robust to heteroskedasticity. For coefficients in the models, t-statistics are reported in parentheses. For the regression diagnostic tests, only p-values in parentheses are reported. *significance at $1 \%, * *$ significance at $5 \%$, ***significance at $10 \%$. 


\subsection{Univariate and Multivariate Analysis}

\subsubsection{Descriptive Variable Statistics}

Descriptive statistics for protecting minority investor protection scores (CG) and subclassification indices scores are shown in Table 2 and are discussed in Section 4.1. I show that for the sampled countries minority investor protection levels are relatively lower relative to the global. Especially, I show that score of ease of shareholder suits sub-classification index is significantly lower for the sampled countries.

Table 7 shows descriptive statistics for the other variables used in regression models. Descriptive statistics for the sample show that the dividend payout ratio for conventional banks with a median of $39 \%$ (mean of $40 \%$ ) is relatively higher than the ratio for Islamic banks with a median of $17 \%$ (mean of 27\%). The difference (MannWhitney $U$-test) shows that the difference of dividend payout ratio between two types of banks is statistically significant. The sample median difference tests ( $U$-test) also show that with the exception of profitability, median values of each variable are significantly different between Islamic and conventional banks.

In addition, Table 7 shows descriptive statistics for the sample banks that payout dividend in any year (i.e., Dividend Paying Sample). For this sub-sample, the median ( $U$-test) results show that except with the exception of leverage and asset compositions, the medians of other explanatory variables are statistically identical between the two types of banks. In particular, both mean and median dividend payout ratios are very similar with values close to $48 \%$. 
Table 7: Descriptive Variable Statistics: Conventional Banks and Islamic Banks (2003-2012)

\begin{tabular}{|c|c|c|c|c|c|c|c|c|c|c|c|c|c|c|}
\hline \multirow[b]{3}{*}{ Variables } & \multicolumn{7}{|c|}{ Sample } & \multicolumn{7}{|c|}{$\begin{array}{l}\text { Div. Paying Sample Banks } \\
\text { (Dividends }>0 \text { ) }\end{array}$} \\
\hline & \multicolumn{3}{|c|}{ Conventional Banks } & \multicolumn{3}{|c|}{ Islamic Banks } & \multirow{2}{*}{$\frac{\text { Diff }}{U \text {-test }}$} & \multicolumn{3}{|c|}{ Conventional Banks } & \multicolumn{3}{|c|}{ Islamic Banks } & \multirow{2}{*}{$\frac{\text { Diff }}{U \text {-test }}$} \\
\hline & Mean & Median & $\begin{array}{c}\text { St. } \\
\text { Dev. }\end{array}$ & Mean & Median & $\begin{array}{l}\text { St. } \\
\text { Dev. }\end{array}$ & & Mean & Median & $\begin{array}{l}\text { St. } \\
\text { Dev. }\end{array}$ & Mean & Median & $\begin{array}{l}\text { St. } \\
\text { Dev. }\end{array}$ & \\
\hline Dividend payout & 0.40 & 0.39 & 0.31 & 0.27 & 0.17 & 0.31 & $5.12 *$ & 0.50 & 0.48 & 0.26 & 0.48 & 0.47 & 0.27 & 0.48 \\
\hline Dividend-to-cash flow & 0.34 & 0.31 & 0.31 & 0.26 & 0.12 & 0.35 & $4.32 *$ & 0.44 & 0.38 & 0.28 & 0.43 & 0.37 & 0.33 & 0.65 \\
\hline Profitability & 0.19 & 0.12 & 0.82 & 0.26 & 0.10 & 1.42 & 0.28 & 0.25 & 0.13 & 0.66 & 0.37 & 0.11 & 1.17 & 0.14 \\
\hline Size & 22.70 & 22.66 & 1.86 & 22.26 & 22.44 & 1.92 & $2.56 * *$ & 22.98 & 22.95 & 1.82 & 22.75 & 23.04 & 2.07 & 0.88 \\
\hline Leverage & 7.24 & 7.10 & 2.98 & 6.83 & 5.71 & 4.95 & $3.39 *$ & 7.20 & 7.20 & 2.60 & 7.25 & 6.01 & 5.12 & $1.89^{* * *}$ \\
\hline Growth & 1.16 & 1.09 & 0.35 & 1.22 & 1.04 & 0.94 & $3.15^{*}$ & 1.15 & 1.09 & 0.37 & 1.25 & 1.07 & 0.73 & 0.43 \\
\hline Asset compositions & 0.66 & 0.69 & 0.17 & 0.52 & 0.55 & 0.20 & $8.59 *$ & 0.66 & 0.69 & 0.15 & 0.52 & 0.59 & 0.21 & $5.89 *$ \\
\hline
\end{tabular}

The table reports descriptive statistics for the variables of both conventional banks (CV) and Islamic banks (IS). It also reports descriptive statistics for the sub-sampled banks (Div. Paying Sample Banks) that pay dividends in any year. Variable descriptions are shown in Table 3. To test median differences, I use the non-parametric median test (Mann-Whitney $U$-test). *significance at $1 \%, * *$ significance at $5 \%, * * *$ significance at $10 \%$. 


\subsubsection{Investor Protection and Interaction Effects}

Table 8 presents the estimation results of random effects and random effects Tobit regressions on the model (1). As I explained in Section 4.3, I focus on the random effects Tobit regressions estimation results for models due to the statistically significant of Log likelihood ratio test. I also include marginal effects $\left(\mathrm{d}_{\mathrm{y}} / \mathrm{d}_{\mathrm{x}}\right)$ of the estimated coefficients, which are computed at the mean. I compute marginal effects for the unconditional expected value of the dependent variable (Adjaoud and Ben-Amar, 2010).

For the Islamic banks, the estimation results show that protecting minority investor scores (CG) and Growth are statistically significant and have negative and positive effects on Islamic bank dividend payouts, respectively. These signs are in line with expected signs for the substitute agency model of dividends. In countries with low levels of investor protection, shareholders, and especially minority shareholders, are more likely to respond with bank management expropriation and shareholder control. The higher protecting minority investor scores (CG) is, the lesser the need to use dividend policies as a substitute mechanism. In other words, higher dividend payouts are not needed to establish a good reputation. The positive effect of growth opportunities strengthens the finding that Islamic banks follow the substitute model. Islamic banks are more likely to payout dividends even if they have growth opportunities. They use dividend policies as a substitute mechanism to establish a good reputation and indicate the degree of their quality.

For the conventional banks, protecting minority investor scores (CG) has a positive sign but is not statistically significant. Growth has a negative coefficient and is statistically significant. These signs are in line with expected signs for the outcome agency 
model of dividends. As discussed in the Introduction, these findings for conventional banks support LLSV's "testable implication" argument for the outcome agency model of dividends. The control variable results are in line with previous empirical findings presented in the literature. Profitability and size have statistically positive coefficients for both Islamic and conventional banks. Similarly, the sign of the asset compositions control variable is consistent with sign predictions shown in Table 3, and it is only significant for Islamic banks. Leverage is statistically significant for both; however, the negative sign found for Islamic bank leverage is not in line with predictions.

Table 8: Dividend Payouts: Investor Protection and Growth

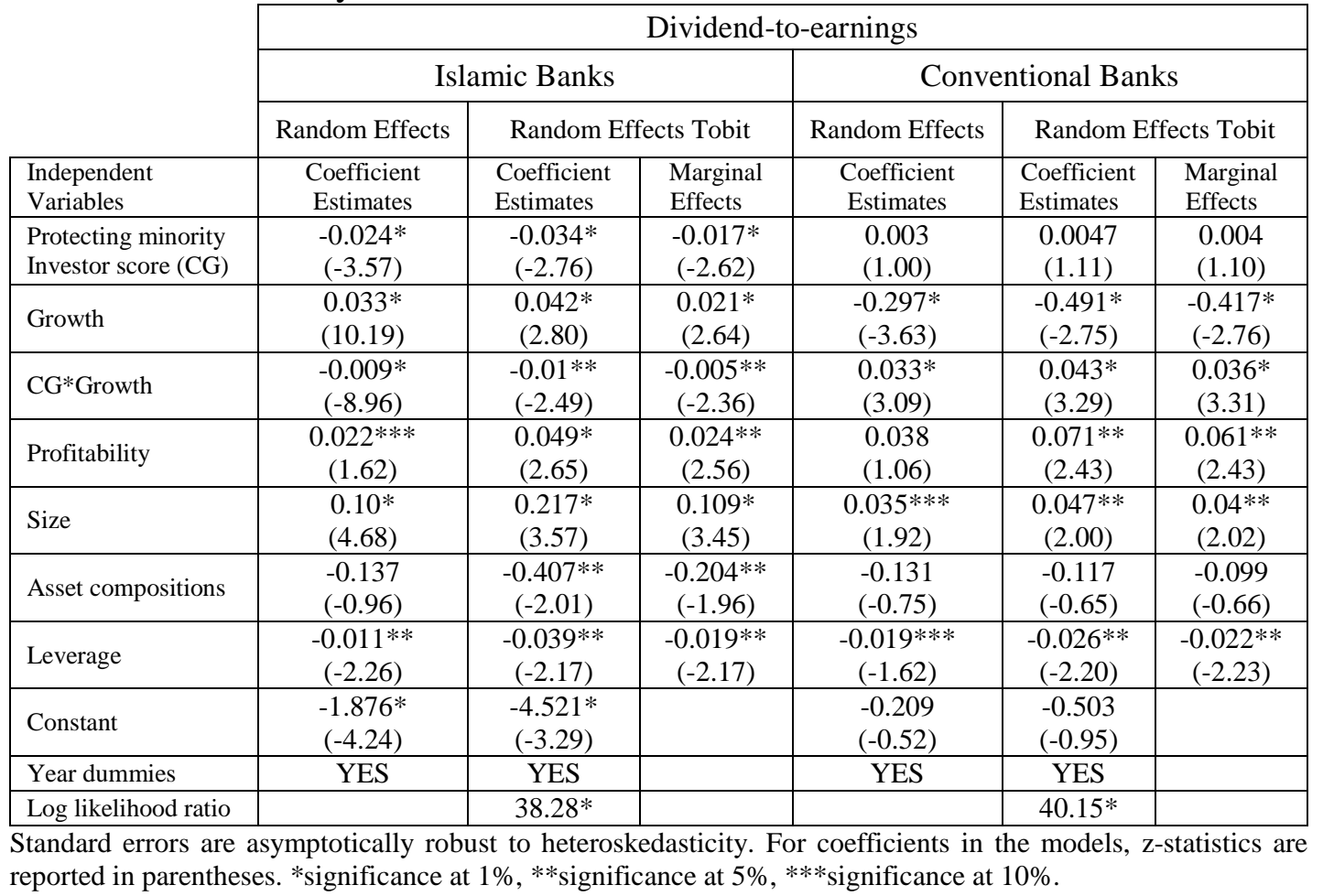


In Table 8, the estimation results show that coefficients of the interaction effect between protecting minority investor scores and growth (CG*Growth) are statistically significant for both types of banks, though the signs are not the same. To facilitate a more precise interpretation of interaction effects, I focus on CG and Growth variables (i.e., subtract the mean of each variable) and assume that the effects of other explanatory variables are equal to zero. Figure 3 and 4 show interactive effects of Growth and CG on dividend payouts for both Islamic and conventional banks. Lines are drawn for Growth values of 1, 1.5 and 2. Figure 3 shows that for countries with average CG, Growth positively affects Islamic bank dividend payouts. In countries with below-average $\mathrm{CG}$, the positive slope is steeper, indicating that the substitute effect is stronger. Similarly, in countries with above-average CG, the line is still positively sloped but is less steep. Positive slopes become less steep from belowaverage to average $\mathrm{CG}$ countries and from average to above-average $\mathrm{CG}$ countries. Figure 3 shows that Islamic banks set dividend payouts in line with substitute agency model of dividend predictions.

The downward sloping lines in Figure 4 show that conventional banks set their dividend payouts differently. Negative slopes of the lines for all three cases of CG (i.e., above-average, below-average and average CG) support the finding that conventional banks follow the outcome agency model of dividends. In countries with belowaverage $\mathrm{CG}$, the negative slope is steeper, indicating that the outcome effect is stronger. Similarly, in countries with above-average CG, the line is still negatively sloped but is less steep. In line with predictions of the outcome agency model, negative slopes become less steep from below-average to average CG countries and from average to above-average CG countries. For the conventional banks, these results shed light on "testable implications" of the outcome model, and I find a negative 
relationship between dividend payouts and growth opportunities in environments with low levels of investor protection.

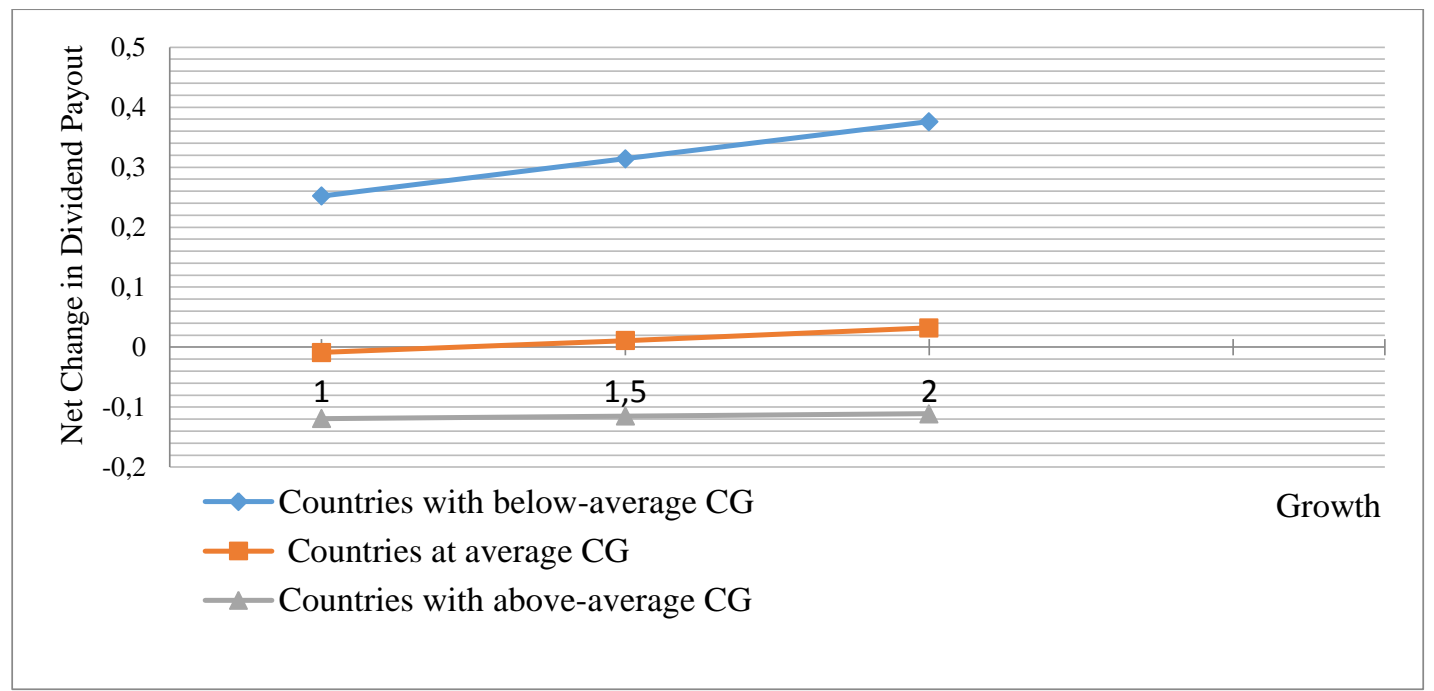

Figure 3: Islamic Banks Dividend Payouts (Dividend-to-earnings): Investor Protection and Growth Interaction Effect

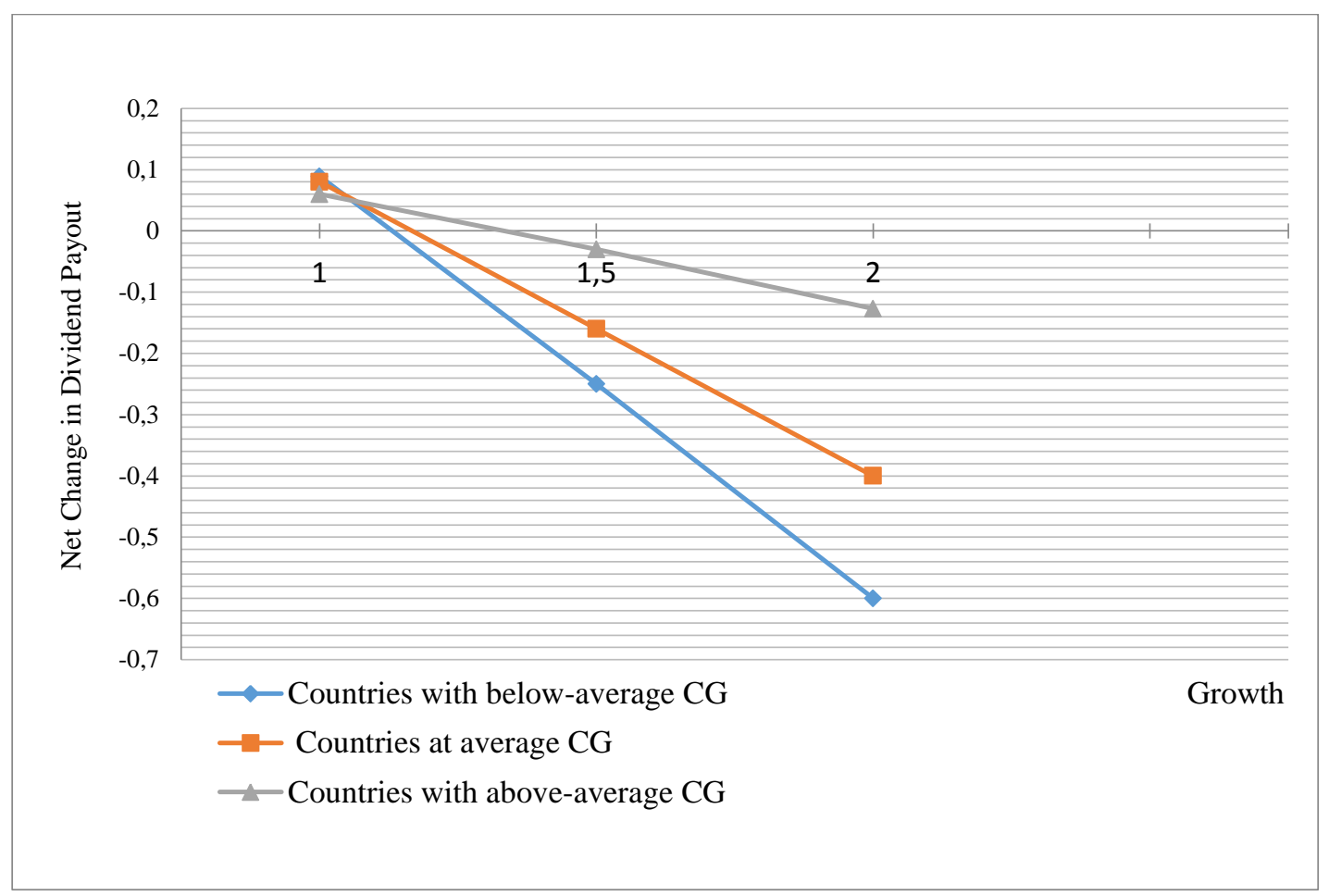

Figure 4: Conventional Banks Dividend Payouts (Dividend-to-earnings): Investor Protection and Growth Interaction Effect 


\subsubsection{Investor Protection: Sub-Classification Index Effects}

Table 9 presents estimation results of random effects and random effects Tobit regressions of equation (2). More specifically, Table 9 shows how each minority investor protection score $(\mathrm{CG})$ sub-classification index affects dividend payouts. The results of the random effects and random effects Tobit regressions are consistent with each other, though I focus on the random effects Tobit regression results.

In Table 9, the ease of shareholder suits index has a negative sign for both types of banks, but it is only statistically significant for Islamic banks. The marginal effect shows that any increase in the ease of shareholder suits index decreases the dividend payout. This empirical finding supports the substitute model for Islamic banks. The stronger the legal system (i.e., easy access to internal documents, evidence, and fair legal expense allocation), the lesser the need to use dividend policies as a reputation building mechanism. Director liability and disclosure indices have positive coefficients for both types of banks, but the extent of the disclosure index is only statically significant for conventional banks. This means that any increase in the disclosure index increases the dividend payout. This interpretation is in line with the outcome model. Overall, for Islamic banks, the shareholder suits index stands out, whereas for conventional banks, the disclosure index is prominent. In particular, results found for Islamic banks confirm the importance of legal systems (i.e., Sharia Law), as shown in LLSV's (2000) study.

As a summary, Islamic banks increase dividends in response to weak minority investor protection, specifically the inability of shareholders to get corporate documents during litigation against firms. In contrast, conventional banks increase dividends in response to stronger minority investor protection, specifically for the amount of dis- 
closure of related party transactions. Similarly, the coefficient signs for control variables are identical with the results shown in Table 8 , and the only negative sign for leverage variable is not in line with above-mentioned predictions presented in Table 3.

Table 9: Dividend Payouts: Investor Protection Sub-Classification Index Effects

\begin{tabular}{|c|c|c|c|c|c|c|}
\hline \multirow{4}{*}{$\begin{array}{l}\text { Independent } \\
\text { Variables }\end{array}$} & \multicolumn{6}{|c|}{ Dividend-to-earnings } \\
\hline & \multicolumn{3}{|c|}{ Islamic Banks } & \multicolumn{3}{|c|}{ Conventional Banks } \\
\hline & \multirow{2}{*}{$\begin{array}{c}\text { Random Effects } \\
\text { Coefficient } \\
\text { Estimates } \\
\end{array}$} & \multicolumn{2}{|c|}{ Random Effects Tobit } & \multirow{2}{*}{$\begin{array}{c}\text { Random Effects } \\
\text { Coefficient } \\
\text { Estimates } \\
\end{array}$} & \multicolumn{2}{|c|}{ Random Effects Tobit } \\
\hline & & $\begin{array}{l}\text { Coefficient } \\
\text { Estimates }\end{array}$ & $\begin{array}{c}\text { Marginal } \\
\text { Effects }\end{array}$ & & $\begin{array}{l}\text { Coefficient } \\
\text { Estimates }\end{array}$ & $\begin{array}{c}\text { Marginal } \\
\text { Effects }\end{array}$ \\
\hline Suits index & $\begin{array}{c}-0.333^{*} \\
(-3.81) \\
\end{array}$ & $\begin{array}{c}-0.598 * * \\
(-2.50) \\
\end{array}$ & $\begin{array}{c}-0.306^{* *} \\
(-2.44) \\
\end{array}$ & $\begin{array}{l}-0.075 \\
(-0.76) \\
\end{array}$ & $\begin{array}{l}-0.084 \\
(-0.82) \\
\end{array}$ & $\begin{array}{l}-0.071 \\
(-0.82) \\
\end{array}$ \\
\hline Liability index & $\begin{array}{c}0.02 \\
(0.28) \\
\end{array}$ & $\begin{array}{l}0.013 \\
(0.07) \\
\end{array}$ & $\begin{array}{l}0.007 \\
(0.07) \\
\end{array}$ & $\begin{array}{l}0.023 \\
(0.25) \\
\end{array}$ & $\begin{array}{l}0.029 \\
(0.29) \\
\end{array}$ & $\begin{array}{l}0.024 \\
(0.29) \\
\end{array}$ \\
\hline Disclosure index & $\begin{array}{l}0.072 \\
(1.02) \\
\end{array}$ & $\begin{array}{l}0.121 \\
(0.64)\end{array}$ & $\begin{array}{l}0.062 \\
(0.64) \\
\end{array}$ & $\begin{array}{c}0.131 * * * \\
(1.93)\end{array}$ & $\begin{array}{c}0.145^{* * *} \\
(2.24)\end{array}$ & $\begin{array}{c}0.123 * * \\
(2.26)\end{array}$ \\
\hline Growth & $\begin{array}{c}0.002^{*} \\
(5.96) \\
\end{array}$ & $\begin{array}{c}0.004 * * \\
(2.08)\end{array}$ & $\begin{array}{c}0.002 * * \\
(2.17) \\
\end{array}$ & $\begin{array}{c}-0.193 * * \\
(-2.22) \\
\end{array}$ & $\begin{array}{c}-0.333 * * \\
(-2.00) \\
\end{array}$ & $\begin{array}{c}-0.282 * * \\
(-2.00) \\
\end{array}$ \\
\hline Profitability & $\begin{array}{c}0.025^{* * * *} \\
(1.77) \\
\end{array}$ & $\begin{array}{c}0.053^{*} \\
(2.85) \\
\end{array}$ & $\begin{array}{l}0.027^{*} \\
(2.74) \\
\end{array}$ & $\begin{array}{l}0.043 \\
(1.19) \\
\end{array}$ & $\begin{array}{c}0.076^{* * *} \\
(2.54) \\
\end{array}$ & $\begin{array}{c}0.064^{* *} \\
(2.54) \\
\end{array}$ \\
\hline Size & $\begin{array}{c}0.111^{*} \\
(4.42) \\
\end{array}$ & $\begin{array}{l}0.212 * \\
(3.91) \\
\end{array}$ & $\begin{array}{l}0.108^{*} \\
(3.84) \\
\end{array}$ & $\begin{array}{l}0.025 \\
(1.02) \\
\end{array}$ & $\begin{array}{l}0.036 \\
(1.15) \\
\end{array}$ & $\begin{array}{l}0.031 \\
(1.16) \\
\end{array}$ \\
\hline Asset compositions & $\begin{array}{c}-0.225 * * * \\
(-1.62)\end{array}$ & $\begin{array}{c}-0.547^{*} \\
(-2.65) \\
\end{array}$ & $\begin{array}{l}-0.28^{*} \\
(-2.57) \\
\end{array}$ & $\begin{array}{l}-0.074 \\
(-0.43) \\
\end{array}$ & $\begin{array}{l}-0.063 \\
(-0.33) \\
\end{array}$ & $\begin{array}{l}-0.053 \\
(-0.33) \\
\end{array}$ \\
\hline Leverage & $\begin{array}{c}-0.01 \\
(-1.38) \\
\end{array}$ & $\begin{array}{c}-0.032 * * * \\
(-1.82)\end{array}$ & $\begin{array}{c}-0.016 * * * \\
(-1.82)\end{array}$ & $\begin{array}{l}-0.014 \\
(-1.32) \\
\end{array}$ & $\begin{array}{c}-0.019 * * * \\
(-1.62)\end{array}$ & $\begin{array}{c}-0.016^{* * * *} \\
(-1.63)\end{array}$ \\
\hline Constant & $\begin{array}{l}-2.091^{*} \\
(-3.91) \\
\end{array}$ & $\begin{array}{c}-4.301^{*} \\
(-3.66) \\
\end{array}$ & & $\begin{array}{l}0.145 \\
(0.26) \\
\end{array}$ & $\begin{array}{c}0.04 \\
(0.06) \\
\end{array}$ & \\
\hline Year dummies & YES & YES & & YES & YES & \\
\hline Log likelihood ratio & & $37.67 *$ & & & $34.52 *$ & \\
\hline
\end{tabular}

Standard errors are asymptotically robust to heteroskedasticity. For the model coefficients, z-statistics are reported in parentheses. *significance at $1 \%, * *$ significance at $5 \%, * * *$ significance at $10 \%$. 


\section{Chapter6}

\section{ROBUSTNESS CHECKS AND LIMITATIONS}

\subsection{Limitation}

As it is stressed in Mitton's (2004) robustness discussions, I try to correct for any reverse causality effects between minority investor protection and profitability levels and for potential variable omission problems. Mitton stresses empirical complications associated with finding suitable instruments that measure corporate governance quality levels. Moreover, Mitton finds that firm-level corporate governance explains profitability, resulting in reverse causality problems (i.e., endogeneity). As discussed in the Introduction Section, companies with growth opportunities may enjoy higher levels of profitability and thus higher dividends. This may weaken the relationship between the dividend payout and corporate governance quality. I try to control for this problem in all multivariate analysis by not using traditional profitability measures (e.g., ROA and ROE) at time $t$, though I use the change in earnings from $t$ to $t+1$.

\subsection{Robustness Check}

I replicated the estimation models by converting the dependent variable to a dividend-to-cash flow ratio. In Table 10, I estimate model (1), and the results are consistent with results shown in Table 8 with the exception of minority investor protection (CG) results. Unlike the statistically insignificant CG value found for conventional banks, the positive CG coefficient is now statistically significant. This statistically significant positive coefficient supports the finding that conventional banks 
follow the outcome model. The control variable results also are in line with sign predictions shown in Table 3. Size and profitability have positive statistical coefficients for both Islamic and conventional banks. Similarly, the sign of the asset compositions control variables is consistent with sign predictions shown in Table 3; however, it is only significant for Islamic banks. Leverage is only statistically significant for conventional banks, and the negative sign found for Islamic bank leverage is not in line with above-mentioned predictions.

Table 10: Dividend Payouts: Investor Protection and Growth

\begin{tabular}{|c|c|c|c|c|c|c|}
\hline \multirow[b]{4}{*}{$\begin{array}{l}\text { Independent } \\
\text { Variables }\end{array}$} & \multicolumn{6}{|c|}{ Dividend-to-cash flow } \\
\hline & \multicolumn{3}{|c|}{ Islamic Banks } & \multicolumn{3}{|c|}{ Conventional Banks } \\
\hline & \multirow{2}{*}{$\begin{array}{c}\text { Random Effects } \\
\text { Coefficient } \\
\text { Estimates }\end{array}$} & \multicolumn{2}{|c|}{ Random Effects Tobit } & \multirow{2}{*}{$\begin{array}{c}\text { Random Effects } \\
\text { Coefficient } \\
\text { Estimates }\end{array}$} & \multicolumn{2}{|c|}{ Random Effects Tobit } \\
\hline & & $\begin{array}{l}\text { Coefficient } \\
\text { Estimates }\end{array}$ & $\begin{array}{l}\text { Marginal } \\
\text { Effects }\end{array}$ & & $\begin{array}{c}\text { Coefficient } \\
\text { Estimates }\end{array}$ & $\begin{array}{l}\text { Coefficient } \\
\text { Estimates }\end{array}$ \\
\hline $\begin{array}{l}\text { Protecting minority } \\
\text { investor score (CG) }\end{array}$ & $\begin{array}{c}-0.305^{*} \\
(-8.55) \\
\end{array}$ & $\begin{array}{c}-0.334 * \\
(-8.70) \\
\end{array}$ & $\begin{array}{c}-0.105^{*} \\
(-5.26) \\
\end{array}$ & $\begin{array}{c}0.007 * * * \\
(1.92)\end{array}$ & $\begin{array}{c}0.008 * * \\
(2.02) \\
\end{array}$ & $\begin{array}{c}0.006^{* *} \\
(2.04) \\
\end{array}$ \\
\hline Growth & $\begin{array}{l}0.522 * \\
(8.30)\end{array}$ & $\begin{array}{l}0.568^{*} \\
(9.73)\end{array}$ & $\begin{array}{l}0.178^{*} \\
(5.29)\end{array}$ & $\begin{array}{c}-0.199 * * \\
(-2.38)\end{array}$ & $\begin{array}{c}-0.378 * * \\
(-2.18)\end{array}$ & $\begin{array}{c}-0.302 * * \\
(-2.19)\end{array}$ \\
\hline CG*Growth & $\begin{array}{c}-0.151^{*} \\
(-8.32) \\
\end{array}$ & $\begin{array}{c}-0.162 * \\
(-9.59) \\
\end{array}$ & $\begin{array}{c}-0.051^{*} \\
(-5.21) \\
\end{array}$ & $\begin{array}{l}0.029 * \\
(2.79)\end{array}$ & $\begin{array}{l}0.039 * \\
(3.04)\end{array}$ & $\begin{array}{l}0.031^{*} \\
(3.05)\end{array}$ \\
\hline Profitability & $\begin{array}{c}0.0008 \\
(0.04)\end{array}$ & $\begin{array}{l}0.086 \\
(1.17)\end{array}$ & $\begin{array}{l}0.027 \\
(1.19)\end{array}$ & $\begin{array}{c}0.077 * * * \\
(1.80)\end{array}$ & $\begin{array}{l}0.12 * \\
(4.12)\end{array}$ & $\begin{array}{c}0.096^{*} \\
(4.10)\end{array}$ \\
\hline Size & $\begin{array}{l}0.058 \\
(1.44) \\
\end{array}$ & $\begin{array}{c}0.28 * * \\
(2.19) \\
\end{array}$ & $\begin{array}{c}0.088^{* *} \\
(2.24)\end{array}$ & $\begin{array}{c}0.034 * * * \\
(1.90) \\
\end{array}$ & $\begin{array}{c}0.046^{* *} \\
(2.04)\end{array}$ & $\begin{array}{c}0.036^{* *} \\
(2.06)\end{array}$ \\
\hline Asset compositions & $\begin{array}{l}0.044 \\
(0.15)\end{array}$ & $\begin{array}{l}-0.483 \\
(-0.69)\end{array}$ & $\begin{array}{c}-0.152 \\
(-0.70)\end{array}$ & $\begin{array}{l}-0.116 \\
(-0.59)\end{array}$ & $\begin{array}{l}-0.115 \\
(-0.65)\end{array}$ & $\begin{array}{l}-0.092 \\
(-0.66)\end{array}$ \\
\hline Leverage & $\begin{array}{c}-0.017 * * \\
(-2.21)\end{array}$ & $\begin{array}{l}-0.059 \\
(-1.34)\end{array}$ & $\begin{array}{l}-0.018 \\
(-1.38)\end{array}$ & $\begin{array}{c}-0.022 * * * \\
(-1.71)\end{array}$ & $\begin{array}{l}-0.03 * \\
(-2.65)\end{array}$ & $\begin{array}{l}-0.024^{*} \\
(-2.69)\end{array}$ \\
\hline Constant & $\begin{array}{l}0.249 \\
(0.26)\end{array}$ & $\begin{array}{c}-4.855^{* * * *} \\
(-1.71)\end{array}$ & & $\begin{array}{l}-0.177 \\
(-0.44)\end{array}$ & $\begin{array}{l}-0.439 \\
(-0.87)\end{array}$ & \\
\hline Year dummies & YES & YES & & YES & YES & \\
\hline Log likelihood ratio & & $82.56^{*}$ & & & $49.56^{*}$ & \\
\hline
\end{tabular}

Standard errors are asymptotically robust to heteroskedasticity. For the model coefficients, z-statistics are reported in parentheses. *significance at $1 \%, * *$ significance at $5 \%, * * *$ significance at $10 \%$. 
In Table 11, I estimate model (2) using the dividend-to-cash flow ratio, and the results confirm the previously estimated effects of different sub-classification indices on dividend payouts for both types of banks. However, for conventional banks, in addition to the disclosure index, there is one more statistically significant index with a positive coefficient: the extent of director liability index. This finding also supports the outcome model and implies that conventional banks payout higher dividends in response to stronger minority investor protection, director liability and amount of disclosure of related party transactions.

Table 11: Dividend Payouts: Investor Protection Sub-Classification Index Effects

\begin{tabular}{|c|c|c|c|c|c|c|}
\hline \multirow{4}{*}{$\begin{array}{l}\text { Independent } \\
\text { Variables }\end{array}$} & \multicolumn{6}{|c|}{ Dividend-to-cash flow } \\
\hline & \multicolumn{3}{|c|}{ Islamic Banks } & \multicolumn{3}{|c|}{ Conventional Banks } \\
\hline & \multirow{2}{*}{$\begin{array}{c}\text { Random Effects } \\
\text { Coefficient } \\
\text { Estimates }\end{array}$} & \multicolumn{2}{|c|}{ Random Effects Tobit } & \multirow{2}{*}{$\begin{array}{c}\text { Random Effects } \\
\text { Coefficient } \\
\text { Estimates }\end{array}$} & \multicolumn{2}{|c|}{ Random Effects Tobit } \\
\hline & & $\begin{array}{l}\text { Coefficient } \\
\text { Estimates }\end{array}$ & $\begin{array}{c}\text { Marginal } \\
\text { Effects }\end{array}$ & & $\begin{array}{l}\text { Coefficient } \\
\text { Estimates }\end{array}$ & $\begin{array}{c}\text { Marginal } \\
\text { Effects }\end{array}$ \\
\hline Suit index & $\begin{array}{l}-0.158 \\
(-0.54) \\
\end{array}$ & $\begin{array}{c}-2.313 * * \\
(-2.02)\end{array}$ & $\begin{array}{c}-0.491 * * \\
(-2.14) \\
\end{array}$ & $\begin{array}{l}-0.103 \\
(-1.19) \\
\end{array}$ & $\begin{array}{l}-0.121 \\
(-1.34) \\
\end{array}$ & $\begin{array}{l}-0.097 \\
(-1.34) \\
\end{array}$ \\
\hline Liability index & $\begin{array}{l}-0.384 \\
(-1.11) \\
\end{array}$ & $\begin{array}{l}0.139 \\
(0.16) \\
\end{array}$ & $\begin{array}{l}0.029 \\
(0.16) \\
\end{array}$ & $\begin{array}{c}0.131 * * * * \\
(1.74) \\
\end{array}$ & $\begin{array}{c}0.146^{* * * *} \\
(1.63) \\
\end{array}$ & $\begin{array}{c}0.117 * * * * \\
(1.64) \\
\end{array}$ \\
\hline Disclosure index & $\begin{array}{l}-0.067 \\
(-0.22)\end{array}$ & $\begin{array}{l}0.383 \\
(0.47)\end{array}$ & $\begin{array}{l}0.081 \\
(0.47)\end{array}$ & $\begin{array}{l}0.179 * \\
(2.73)\end{array}$ & $\begin{array}{l}0.199 * \\
(3.28)\end{array}$ & $\begin{array}{l}0.159 * \\
(3.32)\end{array}$ \\
\hline Growth & $\begin{array}{c}0.004 * * * \\
(1.62)\end{array}$ & $\begin{array}{l}0.015 \\
(1.50)\end{array}$ & $\begin{array}{l}0.003 \\
(1.58)\end{array}$ & $\begin{array}{c}-0.147 * * \\
(-1.95)\end{array}$ & $\begin{array}{c}-0.283 * * * \\
(-1.76)\end{array}$ & $\begin{array}{c}-0.227 * * * \\
(-1.76)\end{array}$ \\
\hline Profitability & $\begin{array}{c}0.05 \\
(1.11)\end{array}$ & $\begin{array}{l}0.28 * * \\
(2.35)\end{array}$ & $\begin{array}{l}0.059 * * \\
(2.35)\end{array}$ & $\begin{array}{l}0.081 * * \\
(1.97)\end{array}$ & $\begin{array}{l}0.124^{*} \\
(4.27) \\
\end{array}$ & $\begin{array}{l}0.10^{*} \\
(4.26)\end{array}$ \\
\hline Size & $\begin{array}{l}0.007 \\
(0.09) \\
\end{array}$ & $\begin{array}{c}0.45 * * * \\
(1.94)\end{array}$ & $\begin{array}{l}0.095 * * \\
(2.05)\end{array}$ & $\begin{array}{l}0.015 \\
(0.63)\end{array}$ & $\begin{array}{l}0.025 \\
(0.87) \\
\end{array}$ & $\begin{array}{c}0.02 \\
(0.87) \\
\end{array}$ \\
\hline Asset compositions & $\begin{array}{l}-1.40 \\
(-1.21) \\
\end{array}$ & $\begin{array}{l}-2.64 * * \\
(-2.23) \\
\end{array}$ & $\begin{array}{c}-0.561^{* *} \\
(-2.23) \\
\end{array}$ & $\begin{array}{l}-0.032 \\
(-0.17) \\
\end{array}$ & $\begin{array}{c}-0.03 \\
(-0.17) \\
\end{array}$ & $\begin{array}{l}-0.024 \\
(-0.17) \\
\end{array}$ \\
\hline Leverage & $\begin{array}{c}-0.06 \\
(-1.30) \\
\end{array}$ & $\begin{array}{l}-0.129 \\
(-1.48) \\
\end{array}$ & $\begin{array}{l}-0.027 \\
(-1.45) \\
\end{array}$ & $\begin{array}{l}-0.013 \\
(-1.06) \\
\end{array}$ & $\begin{array}{c}-0.019^{* * * *} \\
(-1.70) \\
\end{array}$ & $\begin{array}{c}-0.015^{* * * *} \\
(-1.71) \\
\end{array}$ \\
\hline Constant & $\begin{array}{l}1.551 \\
(0.55)\end{array}$ & $\begin{array}{c}-8.395 * * * \\
(-1.68)\end{array}$ & & $\begin{array}{l}0.249 \\
(0.48)\end{array}$ & $\begin{array}{l}0.173 \\
(0.27)\end{array}$ & \\
\hline Year dummies & YES & YES & & YES & YES & \\
\hline Log likelihood ratio & & $29.88^{*}$ & & & $54.03^{*}$ & \\
\hline
\end{tabular}

Standard errors are asymptotically robust to heteroskedasticity. For the model coefficients, z-statistics are reported in parentheses. *significance at $1 \%, * *$ significance at $5 \%, * * *$ significance at $10 \%$. 
Additionally, as shown in Figure 3 and 4, I replicate the analysis using dividend-tocash flows. Figure 5 and 6 show interactive effects of Growth and minority investor protection scores (CG) on dividend payouts for both Islamic and conventional banks. Similar to Figure 3, the results show that for countries with average CG, Growth positively affects Islamic bank dividend payouts. However, it shows the substitute effect is not the same and in countries with below-average CG, the substitute effect is stronger relative to countries with above-average CG. Positive slopes become less steep from below-average to average CG countries and from average to aboveaverage CG countries. The results also confirm that Islamic banks set dividend policies in line with substitute agency model of dividends predictions. Both Figure 3 and 5 emphasize that Islamic banks use dividend policy as a substitute mechanism to alleviate relatively higher agency problems.

In Figure 6, the negative slopes of the lines for all three cases of CG (i.e., aboveaverage, below-average and average CG) shows that conventional set their dividend payouts in line with the outcome agency model of dividends. In line with predictions of the outcome agency model, negative slopes become less steep from below-average to average $\mathrm{CG}$ countries and from average to above-average $\mathrm{CG}$ countries. The negative steeper slope relies on stronger the outcome effect. The results support a negative relationship between dividend payouts and growth opportunities in environments with low levels of investor protection. As a summary, the empirical findings show that conventional and Islamic banks set their dividend policies differently. Conventional and Islamic banks set their dividend policies in line with the outcome and substitute agency models, respectively. 


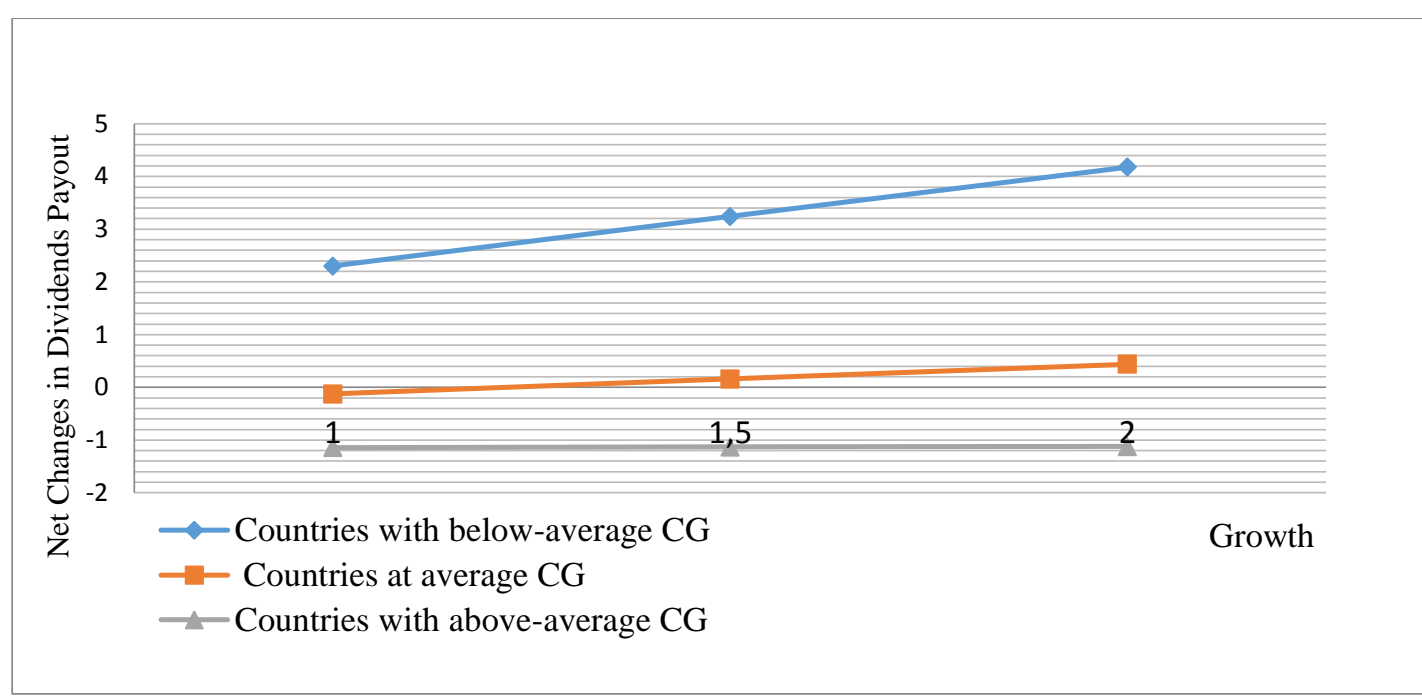

Figure 5: Islamic Banks Dividend Payouts (Dividend-to-cash flow): Investor Protection and Growth Interaction Effect

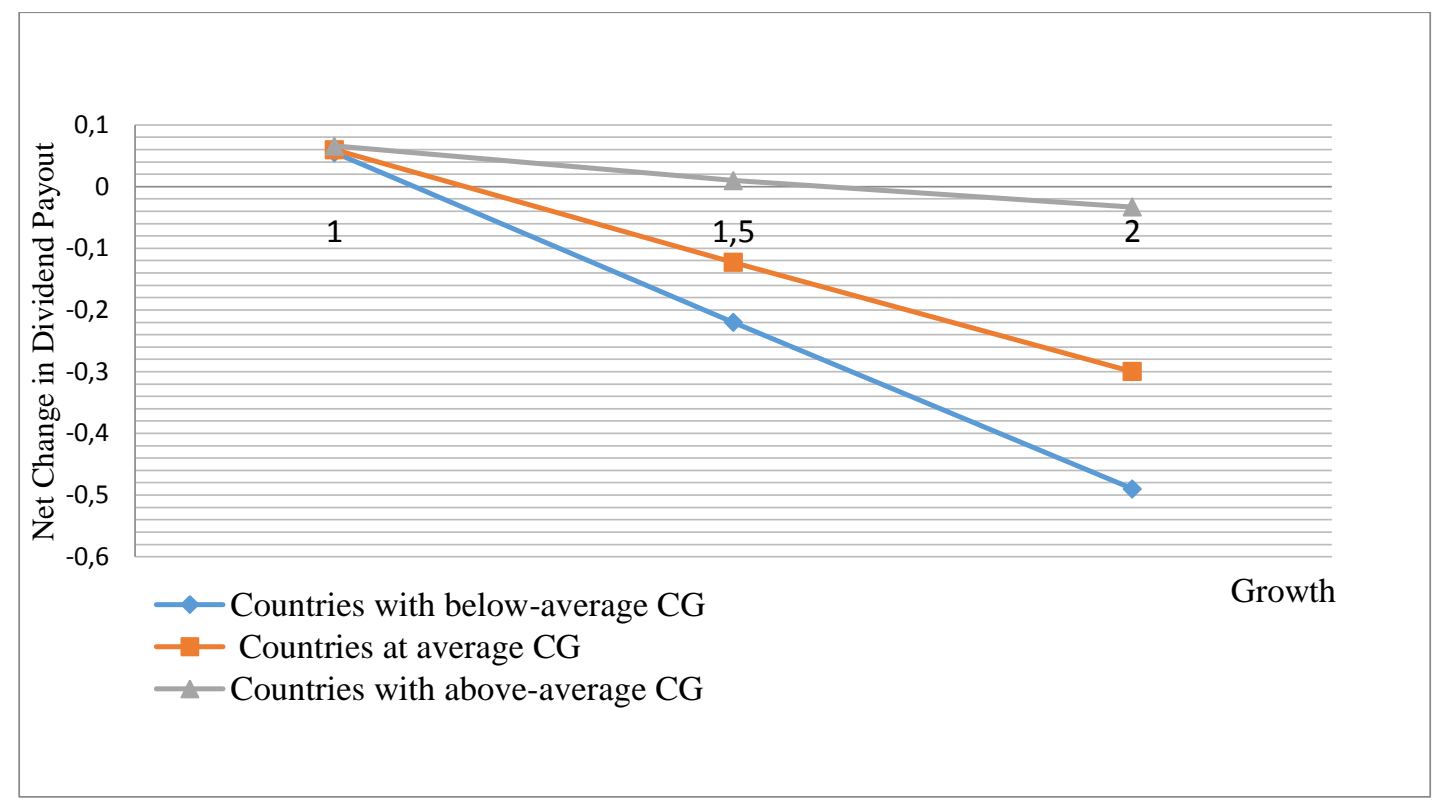

Figure 6: Conventional Banks Dividend Payouts (Dividend-to-cash flow): Investor Protection and Growth Interaction Effect 


\section{Chapter 7}

\section{CONCLUSION AND RECOMMENDATION}

\subsection{Conclusion}

The relationship between legal origin and investor protection has not been examined in the case of financial firms operating under low levels of investor protection and in Sharia law settings. I examine the dividend policy behavior of Islamic and conventional banks operating in Arab markets that have lower minority investor protection and adapt Sharia law in their financial activities. I examine the relationship between investor protection and dividend policy within the framework of agency theory and use the protecting minority investor score to measure investor protection. In contrast to conventional banks, Islamic banks have more pronounced agency problems and greater risks of expropriation by insiders. In line with agency theory prediction, I expect that Islamic banks are more likely to have stable dividend payments and higher dividend payout relative to conventional banks.

Contrary to the agency theory prediction, dividend stability results show that conventional banks have more stable dividend payments and have higher target dividend payouts relative to Islamic banks. While both Islamic and conventional banks operate under low levels of investor protection, conventional and Islamic banks do not have the identical dividend policies and they set dividend policies differently. Empirical findings show that conventional banks set their dividend policies in line with the outcome agency model of dividends. Conventional banks experience less pronounced 
agency problems and lower risks of expropriation by insiders. Dividends are the outcome of strong protection for shareholder rights, whereby shareholders can pressure insiders to pay out free cash flows. Conventional banks increase dividends in response to stronger minority investor protection, specifically for the director liability and the amount of disclosure of related party transactions. These banks uphold international accounting standards and operate in a more competitive environment characterized by greater access to domestic and international financial markets and instruments. In addition, for conventional bank depositors, the deposit insurance system is more protective.

In contrast to conventional banks dividend policies, Islamic banks set their dividend policies in line with the substitute agency model of dividends. Islamic banks have more pronounced agency problems and greater risks of expropriation by insiders. Islamic banks increase dividends in response to weak minority investor protection, specifically the inability of shareholders to get corporate documents during litigation against firms. The empirical findings show that Islamic banks use dividend policies as a substitute mechanism in order to mitigate relatively higher agency costs and establish a good reputation.

The empirical results support the findings (Aivazian et al., 2003; LLSV, 2000) and show that investor protection has a positive effect on the extent of capital market developments and dividend policies. When functioning under low levels of investor protection and Sharia law settings, my findings show that conventional banks due to the relatively better quality of corporate governance and greater accessibility to capital markets have more stable dividend payments and have higher dividend payouts relative to Islamic banks. These findings also support the validity of the outcome 
agency dividend model for convention banks and the validity of the substitute model for Islamic banks.

\subsection{Recommendation}

Although legal systems and country-level investor protection levels affect dividend policies, the results suggest that these implications can differ for companies operating in sectors with unique settings. In addition to country-level investor protection, studies show that firm-level corporate governance is associated with the dividend policies. Mitton (2004) show country-level investor protection and firm-level corporate governance are complement. He shows firm-level corporate governance is an important factor in preventing shareholder expropriation as well as country-level investor protection. Additionally, Francis et al. (2013) show that firm-level corporate governance matter more significantly in countries with low levels of investor protection. I add a third dimension to this nexus; sectorial settings. Further research may focus on bank-specific and country-level scores and may test whether these serve as substitutes or complement in the case of Islamic and conventional banks. 


\section{REFERENCES}

Abdullah Nadwi, M. (2012). Analyzing the role of Sharia supervisory boards in Islamic financial institutions. Working Paper. doi.org/10.2139/ssrn.2217926.

Accounting \& Auditing Organization for Islamic Financial Institutions (AAOIFI), (1993). Concepts of financial accounting for Islamic banks and financial institutions (Financial accounting statement no. 2). Manama, Bahrain: AAOIFI.

Accounting \& Auditing Organization for Islamic Financial Institutions (AAOIFI). (2008). Accounting, auditing and governance standards for Islamic financial institutions: the full text of accounting, auditing and governance standards for Islamic financial institutions as at Jumada II 1429H-June 2008. Bahrain.

Adaoglu, C. (2000). Instability in the dividend policy of the Istanbul stock exchange (ISE) corporations: evidence from an emerging market. Emerging Markets Review, 1, 252-270.

Adjaoud, F., \& Ben-Amar, W. (2010). Corporate governance and dividend policy: shareholders' protection or expropriation?. Journal of Business Finance \& Accounting, 37, 648-667.

Aggarwal, R.K., \& Yousef, T. (2000). Islamic banks and investment financing. Journal of Money, Credit and Banking, 32, 93-120. 
Ahmad, A. U. F., \& Hassan, M. K. (2007). Regulation and performance of Islamic banking in Bangladesh. Thunderbird International Business Review,492, 251-277.

Ahmed, H., \& Javid, A.Y. (2009). Determinants of dividend policy in Pakistan. International Research Journal of Finance and Economics, 29, 110- 125.

Aivazian, V., Booth, L., \& Cleary, S. (2003). Dividend policy and the organization of capital markets. Journal of multinational financial management, 13, 101-121.

Akpomi, M., \& Nnadi, M. (2008). The effect of taxes on dividend policy of banks in Nigeria. International Research Journal of Finance and Economics, 19, 48-55.

Al-Deehani, T., Karim, R.A.A., \& Murinde, V. (1999). The capital structure of Islamic banks under the contractual obligation of profit sharing. International Journal of Theoretical and Applied Finance, 2, 243-283.

Algaoud, L.M. \& Lewis, M.K. (1999). Corporate governance in Islamic banking: the case of Bahrain. The International Journal of Business Studies, 7 1, 56-86.

Algaoud, L.M., \& Lewis, M.K. (2007). Islamic critique of conventional financing. In: Hassan, M.K., Lewis, M.K (Eds.), Handbook of Islamic Banking (pp. 38-48). Edward Elgar Publishing Limited., Cheltenham, UK.

Al-Kuwari, D. (2009). Determinants of the dividend policy in emerging stock exchanges: The case of GCC countries. Global Economy \& Finance Journal, 2, 3863. 
Ali, M., \& Sarkar, A.A. (1995). "Islamic banking: principles and operational methodology". Thoughts on Economics, 5, 20-25.

Allen, F., \& Michaely, R. (2003). Payout policy. Handbook of the Economics of Finance, 1, 337-429.

Al-Malkawi, H.A.N. (2007). Determinants of corporate dividend policy in Jordan: an application of the Tobit model. Journal of Economic and Administrative Sciences, 23, 44-70.

Archer, S., \& Karim, R.A.A. (2009). Profit-sharing investment accounts in Islamic banks: regulatory problems and possible solutions. Journal of Banking Regulation, 104, 300-306.

Archer, S., Karim, R.A.A., \& Al-Deehani, T. (1998). Financial contracting, governance structures and the accounting regulation of Islamic banks: an analysis in terms of agency theory and transaction cost economics. Journal of Management and Governance, 2, 149-170.

Arellano, M., \& Bond, S. (1991). Some tests of specification for panel data: Monte Carlo evidence and an application to employment equations. The Review of Economic Studies, 58, 277-297.

Arellano, M., \& Bover, O. (1995). Another look at the instrumental variable estimation of error-components models. Journal of econometrics, 68, 29-51. 
Astrom, Z.H.O. (2011). Enhancing the structure of Islamic banking by lessening the asymmetric information pertaining to profit and loss sharing instruments. $8^{\text {th }}$ International Conferences on Islamic Economics and Finance.

Bacha, O.I. (1995). Conventional versus mudarabah financing: an agency cost perspective. Journal of Islamic Economics, 4, 33-49.

Baker, H.K., Farrelly, G. E., \& Edelman, R. B. (1985). A survey of management views on dividend policy. Financial management, 14, 78-84.

Baker, H.K. (2009). Dividends and dividend policy, John Wiley \& Sons, USA.

Beck, T., Demirgüç-Kunt, A., \& Merrouche, O. (2013). Islamic vs. conventional banking: business model, efficiency and stability. Journal of Banking and Finance. 372 , 433-447.

Ben Naceur, S., Goaied, M., \& Belanes, A. (2006). On the determinants and dynamics of dividend policy. International Review of Finance, 6, 1-23.

Ben Slama Zouari, S., \& Boulila Taktak, N. (2014). Ownership structure and financial performance in Islamic banks: Does bank ownership matter?. International Journal of Islamic and Middle Eastern Finance and Management, 7, 146-160.

Black, F. (1976). The dividend puzzle. The Journal of Portfolio Management, 2, 5-8. 
Blundell, R., \& Bond, S. (1998). Initial conditions and moment restrictions in dynamic panel data models. Journal of Econometrics, 87, 115-143.

Bodla, B.S., Pal, K., \& Sura, J.S. (2007). Examining application of Lintner's dividend model in Indian banking industry. The ICFAI Journal of Bank Management, $6,40-59$.

Bolbol, A.A., \& Omran, M.M. (2005). Investment and the stock market: evidence from Arab firm-level panel data. Emerging Markets Review, 6, 85-106.

Bourkhis, K., \& Nabi, M.S. (2013). Islamic and conventional banks' soundness during the 2007-2008 financial crisis. Review of Financial Economics, 22, 68-77.

Black, F. (1976). The Dividend Puzzle. Journal of Portfolio Management, 2, 5-8.

Casey, K.M., \& Dickens, R.N. (2000). The effects of tax and regulatory changes on commercial bank dividend policy. The Quarterly Review of Economics and Finance, 40, 279-293.

Chapra, M.U. (2007). Challenges facing the Islamic financial industry. In: Hassan, M.K., Lewis, M.K (Eds.), Handbook of Islamic Banking (pp. 325-357). Edward Elgar Publishing Limited., Cheltenham, UK.

Chong, A., \& López-de-Silanes, F. (2006). Corporate Governance and Firm Value in Mexico. Working Paper, No.564, 1-77. Inter-American Development Bank. 
Chong, B.S., \& Liu, M.H. (2009). Islamic banking: interest-free or interest-based?. Pacific-Basin Finance Journal, 17, 125-144.

Čihák, M., \& Hesse, H. (2010). Islamic banks and financial stability: an empirical analysis. Journal of Financial Services Research, 38, 95-113.

Claessens, S., \& Yurtoglu, B.B. (2013). Corporate governance in emerging markets: a survey. Emerging Markets Review, 15, 1-33.

Daradkah, D.A., \& Ajlouni, M.M. (2013). The Effect of Corporate Governance on Bank's Dividend Policy: Evidence from Jordan. Australian Journal of Business and Management Research, 3, 30-39.

Darling, P.G. (1957). The influence of expectations and liquidity on dividend policy. The Journal of Political Economy, 65, 209-224.

DeAngelo, H., \& DeAngelo, L. (1990). Dividend policy and financial distress: An empirical investigation of troubled NYSE firms. The Journal of Finance, 45, $1415-1431$.

Dickens, R.N., Casey, K.M., \& Newman, J.A. (2002). Bank dividend policy: explanatory factors. Quarterly journal of Business and Economics, 41, 3-12.

Djankov, S., La Porta, R., Lopez-de-Silanes, F., \& Shleifer, A. (2008). The law and economics of self-dealing. Journal of Financial Economics, 88, 430-465. 
Doing Business, Doing business 2014: understanding regulations for small and me$\begin{array}{llll}\text { dium-size } & \text { enterprises. } & \text { (2013). } & \text { Retrieved }\end{array}$ http://www.doingbusiness.org/ /media/GIAWB/Doing\%20Business/Documents/ Annual-Reports/English/DB14-Full-Report.pdf

Easterbrook, F.H. (1984). Two Agency-Cost Explanations of Dividends. American Economic Review, 74, 650-659.

El Qorchi, M. (2005). Islamic finance gears up. Finance and Development, 42, 4649.

$\begin{array}{lllll}\text { Ernst } \quad \& \quad \text { Young. } & \text { (Feb 2013). } & \text { Retrieved from }\end{array}$ http://www.ey.com/GL/en/Services/Tax/Global-tax-guide-archive

Ernst \& Young. World Islamic banking competitiveness report 2012-2013. (2012). $\begin{array}{ll}\text { Retrieved from } & \text { from }\end{array}$ http://www.ey.com/Publication/vwLUAssets/The_World_Islamic_Banking_Com petitiveess_Report/\$FILE/World\%20Islamic\%20Banking\%20Competitiveness\%20R eport\%202012-13.pdf

Ernst \& Young, World Islamic banking competitiveness report 2013-2014. (2013). $\begin{array}{ll}\text { Retrieved from } & \text { from }\end{array}$ http://www.ey.com/Publication/vwLUAssets/World_Islamic_Banking_Competiti veness_Report_201314/\$FILE/World\%20Islamic\%20Banking\%20Competitiveness 


\section{\%20Report\%202013-14.pdf}

Fama, E.F., \& Babiak, H. (1968). Dividend policy: an empirical analysis. Journal of the American Statistical Association, 63, 1132-1161.

Fama, E.F., \& French, K.R. (1997). Dividends, debt, investment, and earnings. Center for Research in Security Prices, University of Chicago.

Fama, E.F., \& French, K.R. (2001). Disappearing dividends: changing firm characteristics or lower propensity to pay?. Journal of Financial Economics, 60, 3-43.

Francis, B., Hasan, I., Song, L., \& Waisman, M. (2013). Corporate governance and investment-cash flow sensitivity: evidence from emerging markets. Emerging Markets Review, 15, 57-71.

Garay, U., \& González, M. (2008). Corporate governance and firm value: The case of Venezuela. Corporate governance: an International Review, 16, 194-209.

Glen, J.D., Karmokolias, Y., Miller, R.R., \& Shah, S. (1995). Dividend policy and behavior in emerging markets: To pay or not to pay. The World Bank.

Grais, W., \& Pellegrini, M. (2006). Corporate Governance in Institutions Offering Islamic Financial Services: Issues and Options. Working Paper, vol. 4054, 1-45. World Bank Policy.

Greene, W.H. (2012). Econometric Analysis, seventh ed. Pearson Education, UK. 
Greuning, H.V., \& Iqbal, Z. (2008). Risk Analysis for Islamic Banks. World Bank Publications, Washington, D.C., USA.

Gugler, K., \& Yurtoglu, B.B. (2003). Corporate governance and dividend pay-out policy in Germany. European Economic Review, 47, 731-758.

Gupta, M.C., \& Walker, D.A. (1975). Dividend disbursal practices in commercial banking. Journal of Financial and Quantitative Analysis, 10, 515-529.

Han, K.C., Lee, S.H., \& Suk, D.Y. (1999). Institutional shareholders and dividends. Journal of Financial and Strategic Decisions, 12, 53-62.

Hasan, M., \& Dridi, J. (2010). The Effects of the Global Crisis on Islamic and Conventional Banks: A Comparative Study. Working Papers, vol. 10/261, 1-46. IMF.

Hassan, M.K., \& Bashir, A.H.M. (2003). Determinants of Islamic banking profitability. $10^{\text {th }}$ ERF Annual Conference, Morocco, 16-18.

Hassan, M.K., Farhat, J., \& Al-Zu'bi, B. (2003). Dividend signaling hypothesis and short-term asset concentration of Islamic interest free banking. Islamic Economic Studies, 11, 1-30.

Hassan, M.K., \& Chowdhary, M.A.M (2004). Islamic banking regulations in light of Basel II, paper presented at the 2004 Harvard university Islamic finance forum conference, Boston. 
Holder, M.E., Langrehr, F.W., \& Hexter, J.L. (1998). Dividend policy determinants: An investigation of the influences of stakeholder theory. Financial Management, 27, 73-82.

Imran, K., Usman, M., \& Nishat, M. (2013). Banks dividend policy: evidence from Pakistan. Economic Modelling, 32, 88-90.

Islamic Financial Services Board (IFSB), Guidance Note on the Practice of Smoothing the Profits Payout to Investment Account Holders. (2010). Retrieved from http://www.ifsb.org/standard/Guidance_Note_on_the_Practice_of_Smoothing.pdf

Islamic Financial Services Board (IFSB), Islamic Financial Services Industry Stability Report. (2015). Retrieved from http://www.ifsb.org/docs/2015-05 20IFSB\%20Islamic\%20Financial\%20Services\%20Industry\%20Stability\%20Repo $\underline{\mathrm{rt} \% 202015 \text { final.pdf }}$

Jensen, M.C., \& Meckling, W.H. (1976). Theory of the Firm: Managerial Behavior. Agency Costs and Ownership Structure. Journal of Financial Economics. 3, 305360.

Jensen, M.C. (1986). Agency costs of free cash flow, corporate finance, and takeovers. The American economic review, 76, 323-329.

Jensen, G.R., Solberg, D.P., \& Zorn, T.S. (1992). Simultaneous determination of insider ownership, debt, and dividend policies. Journal of Financial and Quantitative analysis, 27, 247-263. 
Jiraporn, P., Kim, J.C., \& Kim, Y.S. (2011). Dividend payouts and corporate governance quality: An empirical investigation. Financial Review, 46, 251-279.

John, K., \& Knyazeva, A. (2006). Payout Policy, Agency Conflicts, and Corporate Governance. Working Paper. doi.org/10.2139/ssrn.841064

Karim, R.A.A. (1996). The impact of the Basle capital adequacy ratio regulation on the financial and marketing strategies of Islamic banks. International Journal of Bank Marketing, 14, 32-44.

Karim, R.A.A., \& Ali, A.E.T. (1989). Determinants of the financial strategy of Islamic banks. Journal of Business Finance and Accounting, 16, 193-212.

Karim, R.A., \& Archer, S. (2002). Islamic Finance: Innovation and Growth. Euromoney, London.

Keen, H, Jr. (1978). Bank dividend cuts: recent experience and the traditional view. Business Review, 3-13.

Kennedy, W.F., \& Scott, D.F, Jr. (1984). An analysis of large bank dividend policy. Review of Business and Economic Research, 20, 28- 38.

Kennedy, W.F., \& Nunnally, B.H. (1986). An empirical examination of large bank dividend payout ratios, 1982-83. Financial Review, 21, 48. 
Khan, M. (1986). Islamic interest-free banking: A theoretical analysis. International Monetary Fund, 33, 1-27.

Khan, T. (2006). Company dividends and ownership structure: evidence from UK panel data. The Economic Journal, 116, 172-189.

Kim, B.S., \& Maddala, G.S. (1992). Estimation and specification analysis of models of dividends behavior based on censored panel data. Empirical Economics, 17, 111124.

Kowalewski, O., Stetsyuk, I., \& Talavera, O. (2008). Does corporate governance determine dividend payouts in Poland?. Post-Communist Economies, 20, 203-218.

La Porta, R., Lopez-de-Silanes, F., Shleifer, A., \& Vishny, R.W. (1998). Law and finance. Journal of Political Economy, 106, 1113-55.

La Porta, R., Lopez-de-Silanes, F., Shleifer, A., \& Vishny, R.W. (1999). Investor Protection: Origins, Consequences, and Reform. Working Paper, vol.7428, 1-44. National Bureau of Economic Research.

La Porta, R., Lopez-de-Silanes, F., Shleifer, A., \& Vishny, R.W. (2000). Agency problems and dividend policies around the world. Journal of Finance, 55, 1-33.

Lee, S.W. (2009). Determinants of dividend policy in Korean banking industry. Banks and Bank Systems, 4, 67-71. 
Li, Y., Hassan, A., Abdirashid, E., Zeller, B., \& Du, M. (2012). The impact of investor protection on financial performance of Islamic banks: an empirical analysis. Corporate Ownership and Control, 9, 50-60.

Lie, E., \& Lie, H.J. (1999). The role of personal taxes in corporate decisions: An empirical analysis of share repurchases and dividends. Journal of Financial and Quantitative Analysis, 34, 533-552.

Lin, C.T. (2002). Dividend policies, legal regimes and institutional structures in the Asia Pacific region. The Asia Pacific Journal of Economics \& Business, 6, 4-16.

Lintner, J. (1956). Distribution of incomes of corporations among dividends, retained earnings, and taxes. The American Economic Review, 46, 97-113.

Lloyd, W.P., Jahera, J.S,Jr,. \& Page, D.E. (1985). Agency costs and dividend payout ratios. Quarterly Journal of Business and Economics, 24, 19-29.

Mayne, L.S. (1980). Bank dividend policy and holding company affiliation. Journal of Financial and Quantitative Analysis, 15, 469-480.

Mercado-Mendez, J., \& Willey, T. (1995). Agency costs in the banking industry: An examination of ownership behavior, leverage and dividend policies. Journal of Economics and Finance, 19, 105-117.

Miller, M.H., \& Modigliani, F. (1961). Dividend policy, growth, and the valuation of shares. the Journal of Business, 34, 411-433. 
Mirakhor, A., \& Zaidi, I. (2007). Profit-and-loss sharing contracts in Islamic finance. In: Hassan, M.K., Lewis, M.K. (Eds.), Handbook of Islamic Banking. (pp.49-63). Edward Elgar Publishing Limited., Cheltenham, UK.

Mitton, T. (2004). Corporate governance and dividend policy in emerging markets. Emerging Markets Review, 5, 409-426.

Mollah, S., \& Zaman, M. (2015). Shari'ah supervision, corporate governance and performance: Conventional vs. Islamic banks. Journal of Banking \& Finance, 58, 418-435.

Morgan Stanley Capital International (MSCI), MSCI Arabian market index (USD). (2015).

Retrieved

from

https://www.msci.com/resources/factsheets/index_fact_sheet/msci-arabian- mar-

$\underline{\text { kets-index.pdf }}$

Nienhaus, V. (2007). Governance of Islamic banks. In: Hassan, M.K., Lewis, M.K. (Eds.), Handbook of Islamic Banking (pp. 128-143). Edward Elgar Publishing Limited., Cheltenham, UK.

Nnadi, M.A., \& AKPOMI, M.E. (2005). The effect of Taxes on dividend policy of banks in Nigeria. doi.org/10.2139/ssrn.873828.

Omran, M. M., Bolbol, A., \& Fatheldin, A. (2008). Corporate governance and firm performance in Arab equity markets: Does ownership concentration matter?. International Review of Law and Economics, 28, 32-45. 
Perez-Gonzalez, F. (2003). Large Shareholders and Dividends: Evidence from US Tax Reforms. Working Paper. National Bureau of Economic Research.

Poterba, J.M., \& Summers, L.H. (1984). New evidence that taxes affect the valuation of dividends. The Journal of Finance, 39, 1397-1415.

Renneboog, L., \& Trojanowski, G. (2007). Control structures and payout policy. Managerial Finance, 33, 43-64.

Rozeff, M.S. (1982). Growth, beta and agency costs as determinants of dividend payout ratios. Journal of Financial Research, 5, 249-259.

Sarker, M.A.A. (1999). Islamic business contracts, agency problem and the theory of the Islamic firm. International Journal of Islamic Financial Services, 1, 12-28.

Shanmugam, B., \& Zahari, Z.R. (2009). A Primer on Islamic Finance. Research Foundation of CFA Institute.

Shleifer, A., \& Vishny, R.W. (1986). Large shareholders and corporate control. Journal of Political Economy, 94, 461-488.

Siddiqi, M.N. (1985). Insurance in an Islamic Economy. Islamic Foundation, UK.

Srairi, S.A. (2010). Cost and profit efficiency of conventional and Islamic banks in GCC countries. Journal of Productivity Analysis, 34, 45-62. 
Srairi, S. (2013). Ownership structure and risk-taking behavior in conventional and Islamic banks: Evidence for MENA countries. Borsa Istanbul Review, 13, 115127.

Sundararajan, V. (2007). Risk characteristics of Islamic products: Implications for risk measurement and supervision. In: Archer, S., Karim, R.A.A. (Eds.), Islamic Finance: The Regulatory Challenge (pp. 40-68). John Wiley and Sons.

Renneboog, L., \& Trojanowski, G. (2005). Patterns in payout policy and payout channel choice of UK firms in the 1990s. Tilburg University.

Visser, H. (2009). Islamic Finance: Principles and Practice. Edward Elgar Publishing Limited., Cheltenham, UK.

Wen, Y., \& Jia, J. (2010). Institutional ownership, managerial ownership and dividend policy in bank holding companies. International Review of Accounting, Banking and Finance. 2, 8-21.

World Bank Group. Retrieved from http://www.doingbusiness.org/custom-query 
World Bank, Global Financial Development Report. (2014). Retrieved from http://siteresources.worldbank.org/EXTGLOBALFINREPORT/Resources/881609 $\underline{\text { 6-1361888425203/9062080-1364927957721/GFDR }}$

2014_Statistical_Appendix_C.pdf

Zameer, H., Rasool, S., Iqbal, S., \& Arshad, U. (2013). Determinants of dividend policy: A case of banking sector in Pakistan. Middle-East Journal of Scientific Research, 18, 410-424. 


\section{APPENDIX}




\title{
Appendix A: Abstract for the Publication of Thesis in the Journal Emerging Markets Review
}

\section{INVESTOR PROTECTION AND DIVIDEND POLICY: THE CASE OF ISLAMIC AND CONVENTIONAL BANKS}

\author{
Seyed Alireza Athari, Cahit Adaoglu and Eralp Bektas \\ Department of Banking and Finance, Faculty of Business and Economics, \\ Eastern Mediterranean University, Famagusta, North Cyprus, via Mersin 10, Turkey
}

(Received 24 November 2015; accepted 27 April 2016)

\begin{abstract}
This study examines the dividend policy behavior of Islamic and conventional banks operating in Arab markets. These banks operate in an environment of Sharia law and low levels of investor protection. The results support the substitution agency model of dividends for Islamic banks, and Islamic banks use the dividend policy as a substitute mechanism for alleviating relatively more significant agency problems and higher risks of expropriation by insiders. In these markets, conventional banks operate in a more competitive environment and experience relatively less significant agency problems. In contrast to Islamic banks, conventional banks follow the outcome agency model of dividends.
\end{abstract}

Keywords: dividend policy; agency theory; outcome; substitute; Islamic banks; conventional banks

JEL Classification: G21, G35 


\section{Investor protection and dividend policy: The case of Islamic and conventional banks}

\section{Seyed Alireza Athari*, Cahit Adaoglu, Eralp Bektas}

Department of Banking and Finance, Faculty of Business and Economics, Eastern Mediterranean University, Famagusta, North Cyprus, via Mersin, 10, Turky

\section{A R T I C L E I N F O}

\section{Article history:}

Received 24 November 2015

Received in revised form 18 April 2016

Accepted 27 April 2016

Available online 5 May 2016

\section{JEl dassification:}

G21

G35

Keywords:

Dividend policy

Agency theory

Outcome

Substitute

Islamic banks

Conventional banks

\section{A B S T R A C T}

This study examines the dividend policy behavior of Islamic and conventional banks operating in Arab markets. These banks operate in an environment of Sharia law and low levels of investor protection. Our results support the substitution agency model of dividends for Islamic banks, and Islamic banks use the dividend policy as a substitute mechanism for alleviating relatively more significant agency problems and higher risks of expropriation by insiders. In these markets, conventional banks operate in a more competitive environment and experience relatively less significant agency problems. In contrast to Islamic banks, conventional banks follow the outcome agency model of dividends.

(c) 2016 Elsevier B.V. All rights reserved.

Figure 7: Picture of Published Abstract 